This manuscript is a preprint and has been submitted to Basin Research. This manuscript has not undergone peer-review. Subsequent versions of this manuscript may have different content. If accepted, the final version of this manuscript will be available via the 'Peer-reviewed Publication DOI' link on the right-hand side of this webpage. Please feel free to contact any of the authors.

17th August 2020 


\section{Evolution of normal fault displacement and length as the}

\section{2 continental lithosphere stretches}

3 Sophie Pan ${ }^{1 *}$, Rebecca E. Bell ${ }^{1}$, Christopher A-L. Jackson ${ }^{1}$, John Naliboff ${ }^{2}$

4

$5 \quad{ }^{1}$ Basins Research Group (BRG), Earth Science and Engineering, Imperial College, Prince

6 Consort Road, London, SW7 2BP

$7 \quad{ }^{2}$ Department of Earth and Environmental Science, New Mexico Institute of Mining and

8 Technology, NM, USA

9

$10 \quad{ }^{*}$ Corresponding author: Sophie Pan (sophie.pan16@imperial.ac.uk)

\section{HIGHLIGHTS}

14 - 7.2 Myrs after rift initiation, fault trace lengths were established to their near-full lengths

15 - At 28.5 Myrs, fault segment throw profiles were symmetric, but overall fault systems were

$16 \quad$ asymmetric

17 - In the last $67 \%$ of rifting, antithetic faults located in stress shadows remained inactive and

$18 \quad$ under-displaced

19 - We suggest faults grow in alternating phases of fault lengthening and displacement

20 accumulation

21 - Our model suggests the frequently observed D-L scatter reflects fault growth and maturity 


\section{ABSTRACT}

24 Continental rifting is accommodated by the development of normal fault arrays. Fault growth

25 patterns control their related seismic hazards, as well as influencing the tectonostratigraphic

26 evolution, resource extraction and $\mathrm{CO}_{2}$ storage potential of rifts. Our understanding of fault

27 evolution is largely derived by observing the final geometry and displacement (D)-length (L)

28 characteristics of active and inactive fault systems, and by making subsequent inferences on their

29 kinematics. We rarely consider how these properties change through time, and how the growth of

30 individual fault systems relates to the temporal evolution of their host arrays. Here we use 3D

31 seismic reflection and borehole data from the Exmouth Plateau, NW Shelf, Australia to

32 determine the growth of rift-related, crustal-scale fault systems and arrays over geological

33 timescales $\left(>10^{6} \mathrm{Ma}\right)$. The excellent-quality seismic data allows us to reconstruct the entire

34 Jurassic-to-Early Cretaceous fault array over a large area $\left(\sim 1200 \mathrm{~km}^{2}\right)$. We find that fault trace

35 lengths were established early, within the first $7.2 \mathrm{Myr}(8 \%)$ of rifting, and that along-strike

36 migration of throw maxima towards the centre of individual fault systems occurred after $\sim 28.5$

37 Myr (33\%) of rifting. We propose that D and L may scale linearly, but increase via alternating

38 phases of fault lengthening and displacement accumulation. Growth trajectories produce

39 inflections in D-L space, reflecting times when fault lengths and/or displacement saturate a given

40 rock volume, possibly controlled by crustal thickness. At the array-scale, faults located in stress

41 shadows become inactive and appear under-displaced relative to adjacent larger faults, onto

42 which strain localises as rifting proceeds. This implies that the scatter frequently observed in D-L

43 plots can simply reflect fault growth and array maturity. We show that by studying complete rift-

44 related normal arrays rather than individual faults, we can better understand how faults grow and

45 more generally how continental lithosphere deforms as it stretches. 


\section{INTRODUCTION}

47 The formation of extensional basins is controlled by the development of normal faults. Large,

48 basin-bounding fault systems typically grow by the initiation, propagation, interaction, and

49 linkage of smaller fault segments (e.g. Peacock and Sanderson, 1991; Anders and Schlische,

50 1994; Trudgill and Cartwright, 1994; Dawers and Anders, 1995; McLeod et al., 2000). A

51 kinematically linked network of fault segments and systems comprise a fault array. Fault arrays

52 evolve in response to co- and interseismic stress feedbacks between the constituent segments and

53 systems; this can lead to the temporal progression from numerous, short, low-displacement

54 segments to a few, long, high-displacement systems ('strain localisation'; Cowie, 1998;

55 Gawthorpe and Leeder, 2000) (Figure 1).

56 As strain localisation is often associated with an increase in basin subsidence rate, the

57 temporal and spatial evolution of fault arrays are reflected in changes in rift physiography, and

58 the location and rate of generation of accommodation (e.g. Dawers and Underhill, 2000, McLeod

59 et al., 2000). The way in which fault arrays grow therefore strongly influences the size, shape,

60 and distribution of sedimentary depocenters and drainage catchments, which in turn control the

61 location of various energy resources, groundwater reservoirs, and potential $\mathrm{CO}_{2}$ storage sites

62 (e.g. Gawthorpe and Leeder, 2000).

63 Mechanical interactions between adjacent faults profoundly affects the stress-dependent

64 nature of earthquakes in potentially hazardous, seismically active regions (e.g. Harris, 1998;

65 Stein, 1999; Allmendinger et al., 2000; Dolan et al., 2007; Nicol et al., 2010; Mildon et al.,

66 2019). An improved understanding of both long-term fault displacement patterns from ancient

67 fault arrays imaged in seismic reflection data, together with short-term earthquake slip rates most

68 commonly derived from regions of active extension, would allow us to characterise fault growth 
69 and interactions over multiple timescales, from a few seconds up to tens-to-hundreds of millions

70 of years (Allmendinger et al., 2000; Nicol et al., 2010; Nicol et al., 2006; Scholz and Gupta,

71 2010; Nicol et al., 2019). However, our current understanding of fault growth largely stems from

72 detailed studies of individual fault systems (e.g. Walsh et al., 2002; Nicol et al., 2005; Jackson

73 and Rotevatn, 2013; Fossen and Rotevatn, 2016; Nicol et al., 2016; Childs et al., 2017; Jackson

74 et al., 2017), rather than rift-scale fault arrays, thereby often overlooking the important role fault

75 interactions and stress feedbacks may play in controlling the early stages of fault and rift

76 development.

77 Historically, fault growth models have been proposed based on field and subsurface

78 observations of the final geometry of ancient faults, often in the absence of kinematic constraints

79 on how the faults evolved. The key geometric relationship that has been used is the relationship

80 between fault length (L) and maximum fault displacement (D):

81

82

83

84 Where $c$ represents the scaling $\mathrm{D} / \mathrm{L}$ ratio and $n$ represents an exponent value argued to vary from

852 (Watterson, 1986; Walsh and Watterson, 1988) to 1 (Cowie and Scholz, 1992; Dawers et al.,

86 1993; Schlische et al., 1996), with a value of 1 indicating a linear scaling law (i.e. self-similarity)

87 (Fig 2) (see also Marrett and Allmendinger, 1991). The exponent $n$ remains unresolved due to

88 the significant amount of scatter in global D-L profiles (Fig. 2) (Cowie and Scholz, 1992;

89 Dawers et al., 1993; Scholz et al., 1993, Cartwright et al., 1995; Nicol et al., 1996; Cladouhos

90 and Marrett, 1996; Schlische et al., 1996), which may reflect the natural geological variations

91 between study areas (e.g. host rock mechanical properties), and uncertainties in data quality and 
92 sampling approaches (Gillespie et al., 1992; Walsh and Watterson, 1988; Kim \& Sanderson,

93 2005; Walsh et al., 2017). However, it is possible that variations in $n$ reflect fundamentally

94 differing styles of fault growth. For example, current conceptual models suggest that faults may

95 grow by either the: (i) 'propagating model', in which fault displacement and length

96 simultaneously increase, producing a linear growth trajectory (Fig 2; e.g. Walsh and Watterson,

97 1988; Cartwright, 1995; Walsh et al., 2003); or (ii) the 'constant length model', in which faults

98 reach their near-full lengths rapidly before significant displacement accumulation, producing an

99 initially shallow gradient trajectory on D-L plots as the fault lengthens, followed by a near

100 vertical trajectory as the fault accumulates displacement (Fig 2; e.g. Walsh et al., 2002; Meyer et

101 al., 2002; Nicol et al., 2005; Nicol et al., 2016; Childs et al., 2017; Jackson et al., 2017; Rotevatn

102 et al., 2019). The two fault models may represent end-members (Fossen 2016; Childs et al.,

103 2017), leading to the proposition of a hybrid growth model (Rotevatn et al., 2019), in which

104 faults initially lengthen via propagation and linkage for $20-30 \%$ of the fault's lifespan, before

105 later accumulating displacement for the final $70-80 \%$. However, the implications of the

106 constant/hybrid model in D-L space are not yet clear.

107 Our current understanding of fault segment, system and array growth is largely geometric

108 and based on observations from modern extensional basins or ancient basins imaged in seismic

109 reflection data. There are very few studies that provide a temporal framework for the growth of

110 normal fault segments and systems (e.g. Tvedt et al., 2016; Meyer et al., 2002). This is mainly

111 due to the lack of age-constrained growth strata to record the timing of fault activity (e.g. Dawers

112 et al., 1993; Schlische et al., 1996; Peacock and Sanderson, 1991). There are even fewer attempts

113 to determine the evolution of entire fault arrays at the rift scale (e.g. Claringbould et al., 2017).

114 We suspect this may reflect the time-consuming effort required to manually interpret many 
115 seismically imaged normal faults, and to subsequently extract their related geometric properties

116 (i.e. displacement, length). As a result, most studies focus on the growth of large, basin-bounding

117 structures (i.e. major fault systems; e.g. McLeod et al., 2000), whilst ignoring smaller, intra-basin

118 ones (i.e. fault segments; e.g. Tvedt et al., 2002).

119 Here we use 3D seismic reflection and borehole data from the Exmouth Plateau, NW

120 Shelf, Australia to determine the growth of rift-related, crustal-scale fault systems and arrays

121 over geological timescales $\left(>10^{6} \mathrm{Ma}\right)$. This study area was subject to Late Triassic-to-Early

122 Cretaceous extension, forming extremely well-defined and well-imaged normal faults, half-

123 grabens, and grabens (Exon and Willcox., 1978; Mutter and Larson, 1989). The large extent of

124 the study area $\left(1200 \mathrm{~km}^{2}\right)$ is of a comparable size to areas of active continental extension

125 containing large, seismogenic fault arrays, including East Africa (Baker et al., 1972; Albaric et

126 al., 2010; Poggi et al., 2017), Central Italy (Luccio et al., 2010; Collettini and Barchi, 2002;

127 Roberts and Michetti, 2004; Cowie et al., 2013), Central Greece (King et al., 1985; Bell et al.,

128 2009; Taylor et al., 2011), SE Russia (Logatchev and Zorin, 1992; Mats, 1993), western Turkey

129 (Seyitoglu, 1996), and the western USA (Hamilton, 1987; Thatcher et al., 1999). This makes our

130 study area an excellent ancient analogue with which to better understand the geological evolution

131 of areas of active continental extension.

132 To the best of our knowledge, this study is the first to quantify the temporal evolution of a

133 complete rift-scale fault array using geometric observations of all seismically resolvable faults.

134 We first define the present-day structure of the fault array (i.e. the final product of rifting).

135 Second, we use depocentre mapping (via the use of time-thickness maps known as isochrons)

136 and fault displacement backstripping to reconstruct the geometry of the entire fault array at an

137 earlier stage of rifting. This allows us to determine the growth trajectory of individual fault 
138 segments and systems, which we then compare to global D-L datasets (Figure 2). Based on our

139 results, we propose a model for the growth of fault arrays. Our model links our current

140 knowledge of the styles of segment- and system-scale growth (i.e. propagating vs constant length

141 models) to the development of the larger fault array. Our model provides an explanation for the

142 long-recognised scatter observed in global D-L datasets and sheds light on how continental

143 lithosphere stretches during early rifting (e.g. Cowie and Schultz, 1992; Cartwright et al., 1995;

144 Kim and Sanderson, 2005; Rotevatn et al., 2019).

\section{GEOLOGICAL HISTORY}

147 The Thebe dataset is located on the Exmouth Plateau (Exon and Willcox 1978) portion of the

148 Northern Carnarvon Basin, NW Shelf of Australia (Geoscience Australia 2014) (Fig. 3a).

149 Formation of the Northern Carnarvon Basin initiated during the Carboniferous to Permian in

150 response to the breakup of Pangea, with episodic rifting continuing until the Late Cretaceous

151 (Stagg and Colwell, 1994; Driscoll and Karner, 1998). Late Triassic rifting produced NE-

152 trending sub-basins (Fig 3a), until a phase of regional uplift in the Callovian (Barber 1988; Pryer

153 et al., 2002; McCormack and McClay, 2013; Metcalfe, 2013). Extension renewed in the Late

154 Jurassic as the Argo block separated from Gondwana, culminating with seafloor spreading and

155 the opening of the Argo Abyssal Plain during the Hauterivian (Tindale, 1998; Heine and Muller, 156 2005; Gibbons et al., 2012; Metcalfe, 2013). The period of Late Jurassic-to-Early Cretaceous

157 rifting was also characterised by the formation of NE-SW-striking faults, locally reactivating

158 Late Triassic faults (e.g. Jitmahantakul and McClay, 2013; Magee et al., 2016).

159 The stratigraphic framework of the Exmouth Plateau consists of a thick, Upper Triassic pre-

160 rift succession of the fluvio-deltaic and marginal marine deposits of the Mungaroo Formation 
161 (Fig 4) (Tindale et al., 1998; Driscoll and Karner, 1988; Longley et al., 2002). From the Late

162 Triassic to Late Jurassic, a syn-rift succession comprised of shallow marine claystone and

163 limestone of the Brigadier Formation (Late Triassic) and marine claystones of the Athol and

164 Murat formations (Early to Middle Jurassic), were deposited within fault-bound, rift-related

165 depocentres (e.g. Stagg and Colwell, 1994; Tindale et al., 1998; Stagg et al., 2004; Longley et

166 al., 2002). During the Late Jurassic to Early Cretaceous, uplift resulted in a decrease in water

167 depth and an influx of interbedded shale and fluvial deltaic sands of the Barrow Group (Fig 4)

168 (Boyd et al., 1992). In association with the subsequent subsidence, a major transgression resulted

169 in the deposition of a thick succession of post-rift marine deposits of the Muderong Shale,

170 Windalia Radiolarite and Gearle Siltstone, which are collectively known as the Winning Group

171 (Hocking, 1987; Driscoll and Karner, 1998) (Fig. 4).

172

173

174

175

located in the WA-346-P permit area, and two wells (Thebe-1 and Thebe-2) (Fig. 3). The seismic

177 data images to depths of $\sim 4.5 \mathrm{~s}$ TWT $(\sim 3.7 \mathrm{~km})$ and covers $45 \mathrm{~km}$ x $39 \mathrm{~km}$, providing a total

178 areal extent of $1200 \mathrm{~km}^{2}$. Crosslines are spaced at $25 \mathrm{~m}$ and inlines at $12.5 \mathrm{~m}$. The dominant

179 frequency is $45 \mathrm{~Hz}$ at the depth of the studied fault array at Thebe- 1 . From time-depth plots

180 derived from well checkshot data, we estimate the average velocity to be $2480 \mathrm{~m} / \mathrm{s}$ within the

181 Jurassic syn-rift units; when combined with frequency data, this results in an estimated spatial

182 vertical resolution of c. $14 \mathrm{~m}(\lambda / 4)$. Overall, the data quality is excellent throughout and enables a 183 high-resolution analysis of fault structure and evolution. 
The Thebe- 1 and Thebe- 2 wells are drilled in the footwalls of tilted fault blocks (Fig 3b) and collected a standard well-log suite (e.g. gamma ray, density, sonic, checkshot and

186 biostratigraphic data). We choose to present our measurements of fault throw in time (ms TWT)

187 rather than depth, given we are primarily interested in the relative changes of throw rather than

188 absolute values (cf. Tvedt et al., 2016; Jackson et al., 2017), and we do not have a high-

189 resolution 3D velocity model to constrain along-strike changes in velocity. To estimate depth in

190 metres from observations in ms TWT, we have used checkshot data from wells that define a

191 polynomial relationship between time and depth. We have not attempted to decompact our throw

192 values as the loss of throw is likely relatively low $(<15 \%)$ in mixed sand-shale growth sequences

193 that characterise much of the syn- to post-rift succession of the Exmouth Plateau (cf. Taylor et al.

194 2008); we also lack information on sediment compaction parameters from the two wells. For

195 better comparison with global D-L compilations, we converted our throw data to displacement

196 data by assuming an average fault dip of $60^{\circ}$, as this is an average for the faults in this area.

\subsection{Structural framework}

199 We mapped ten horizons throughout the seismic reflection volume (labelled H1 - H10; see

200 ages in Fig 4) to delineate the present basin structure and then unravel the fault evolution. Fault

201 interpretation was conducted throughout the seismic volume, aided by overlaying the dip

202 attribute onto mapped horizons (i.e. the deviation of a seismic reflection from a horizontal plane)

203 (Chopra and Marfurt, 2007). We measured the tip-to-tip lengths of all seismically resolvable,

204 individual fault segments at the base of the syn-rift, given this structural level captured most of

205 the rift-related strain (see Fig 1 for definitions). In D-L plots, we show the scaling properties of

206 individual segments, as well as fault systems (F1-F3). We classify faults systems as major (F1- 
207 F3) if their throw is $>150 \mathrm{~ms}$ (TWT) and minor if their throw is $<150 \mathrm{~ms}$ TWT (labelled on Fig $2083 b)$.

209 Fault throw was constrained by measuring the vertical distance between horizon cut-offs in

210 the footwall and hanging wall on seismic profiles trending perpendicular to local fault strike (cf.

211 McLeod et al., 2000; Tvedt et al., 2013). Values are taken every $100-400 \mathrm{~m}$ along the fault

212 depending on the structural complexity and throw variability along the fault. In the presence of

213 erosional footwall fault scarp degradation and fault-related ductile (continuous) deformation, the

214 horizon cut-offs are projected towards the fault plane along the regional structural trend (e.g.

215 Long and Imber, 2010; Whipp et al., 2014, Bell et al., 2014; Wilson et al., 2015; Barrett et al.

216 submitted).

217

\subsection{Constraining rift evolution}

219 To constrain the fault array evolution, we use isochron (time-thickness) mapping and throw 220 backstripping techniques, which are kinematically constrained by our mapped age-constrained

221 horizons $(\mathrm{H} 2, \mathrm{H} 3, \mathrm{H} 4, \mathrm{H} 8, \mathrm{H} 9$ and H10; Fig 4). The ages of three syn-rift horizons are not

222 constrained by the wells (H5, H6 and H7); their ages are therefore inferred based on an

223 assumption of constant sedimentation rates between bounding, age-constrained horizons (Fig 4).

224 We define H2 (Top Mungaroo; $208.5 \mathrm{Ma}$ ) as the base syn-rift (i.e. the start of rifting), consistent 225 with other publications (e.g. Stagg et al., 2004; Tindale et al., 1998), given we observe no across-

226 fault sediment thickness changes between $\mathrm{H} 1$ and $\mathrm{H} 2$ (Figure 5). Fault activity ceases at H9 (Top

227 Muderong; $113 \mathrm{Ma}$ ), based on observations of no across-fault changes in thickness above H9,

228 which we thus define as top syn-rift (i.e. the end of rifting). Our ages for top and base syn-rift

229 give a total rift duration of $\sim 85.5$ Myr (Fig 4). We produced six isochron maps within the syn-rift 
230 interval (SU1-6; Figs 4 and 6), which we use to constrain patterns of fault-controlled subsidence

231 and thus fault growth (Thorsen, 1963; McLeod et al., 2000; Jackson and Rotevatn, 2013).

232 We use fault throw backstripping to constrain the style and patterns of fault growth (Childs et

233 al., 1993; Rowan et al., 1998; Dutton and Trudgill, 2009, Jackson et al., 2017). Throw

234 backstripping involves the subtraction of fault throw at multiple stratigraphic levels to determine

235 the throw accumulated during deposition of the backstripped unit (see Chapman and Meneilly,

236 1991). Faults can be backstripped using the 'original method' or the 'modified method'. The

237 'original method' directly subtracts throw across a shallower horizon from that of the deeper

238 horizon (Chapman and Meneilly, 1991; Petersen et al., 1992), making no assumptions about fault

239 growth style. The 'modified method' subtracts the maximum throw along the horizon from the

240 entire fault surface. This method implicitly assumes that the studied fault grew in accordance

241 with the propagating fault model (Rowan et al., 1998; Jackson et al., 2017). In this study we use

242 the original method to avoid any a priori assumption of the style of fault growth. We then

243 compare our throw backstripping results with depocenter lengths revealed by isochrons; this

244 allows us to assess fault length at different points in the rift history (cf. Jackson and Rotevatn,

245 2013; Jackson et al., 2017).

246 The Exmouth Plateau was sediment-starved (i.e. underfilled) during Jurassic extension

247 (Marshall and Long, 2013; Gartrell et al., 2016). Because of this, accommodation associated with

248 the very earliest stage of extension may have been unfilled, meaning: (i) we cannot determine if

249 any observed fault lengthening occurred by segment linkage or tip propagation (infilling

250 sediments do not exist to record this); and (ii) our measured trace-lengths may thus have been

251 established earlier (i.e. more quickly) than estimated, such that our estimates should be seen as

252 maximum possible values (Jackson et al., 2017; Lathrop et al. submitted). 
4. RESULTS

\subsection{Structural framework}

\subsubsection{Time-structure maps}

257 We first describe the present-day structure of the study area (Fig 6 and Fig 7). We mapped 258150 faults over an area of $45 \times 39 \mathrm{~km}$ that displace the $208.5 \mathrm{Myr}$ base syn-rift horizon (H2, Top

259 Mungaroo); this surface records the total cumulative rift-related strain of the fault array. The 260 base syn-rift surface also contains the largest number of faults. Faults are strongly segmented, 261 being either hard- and soft-linked across relays (Fig 6a). Fault trace lengths at the structural level

262 of H2 (Top Mungaroo) range from c. $300 \mathrm{~m}$ to $>15000 \mathrm{~m}$, with the largest faults extending 263 beyond the study area (Fig 6).

264 A fault map and rose diagram (Fig 7) reveal the strike and dip direction of the syn-rift fault 265 array at the structural level of H2. Major NE-SW-striking faults define the fault array, with a 266 minor set of E- dipping, N-S striking faults (Fig 7). The main NE-SW-striking population 267 comprises $86 \mathrm{E}$ - dipping faults and $57 \mathrm{~W}$ - dipping faults, although major faults (i.e. F1-F3)

268 exclusively dip westwards, whereas the remaining antithetic faults dip eastward (Figure 7). The 269 antithetic E- dipping faults are spaced $\sim 2 \mathrm{~km}$, whereas fault spacing for the major, W- dipping 270 fault systems is $12-16 \mathrm{~km}$ (labelled on Fig 3b).

271 Time-structure maps reveal a reduction in faulting in the shallower structural levels as faults

272 die-out upwards, with only the major fault systems (F1-F3) present at the top syn-rift horizon

273 (H9; Top Muderong) (Fig 5, Fig 6f). These major fault systems extend upward above H10,

274 where they link to normal faults contained in a widespread polygonal fault array (Fig 5). A series

275 of small en-echelon faults occur at the structural level of H6 ( 143 Myr) and H7 ( 141 Myr), 
276 whereas at deeper levels there is a continuous N-S-striking fault. This observation suggests that

277 faults splay vertically upwards as well as horizontally (i.e. at lateral fault tips) (Fig 6c and d).

278 Cross-cutting relationships suggest that the N-S-striking faults formed before the NE-SW-

279 striking fault population (Fig 5, Fig 6a).

280

281

\subsubsection{Throw distribution}

282 Maximum throw on the syn-rift fault array varies from 10 to $650 \mathrm{~ms}$ TWT $(10-670 \mathrm{~m})$

283 (Figure 8a). Throw varies along-strike on major fault systems F1-F3, with maximum throw (up

284 to $650 \mathrm{~ms}$ TWT) typically occurring near their centres. Throw gently decreases to zero at the

285 tips of fault systems (e.g. F2-a, Fig 8a). Individual segments forming the fault systems may show

286 relatively steep throw gradients towards their tips (e.g. F2-b; see Fig 1 for definitions). Strain is

287 distributed on several splay faults at the ends of fault systems (Figure 9a for location). Overall,

288 the aggregate throw of major faults produce a broadly coherent, symmetric throw shaped profile

289 with a gradual decrease in throw towards the tips (Figure 8a).

290 In detail, however, throw minima exist along many major fault systems (e.g. F2-a, F2-b, F3-

291 b), with these minima tending to correlate with areas where fault systems change strike (F2, F3;

292 Fig 8a). The relay zone between F3-a and F3-b shows a decrease in throw when fault segments

293 overlap (Fig 8a). These two observations suggest major fault systems were previously

294 segmented, at least at this structural level (Figure 8a).

295 In contrast to the major fault systems, minor fault systems typically have a uniform throw

296 value along strike (ranging from 20-80 ms TWT) but exhibit an abrupt decrease in throw towards

297 their tips (Figure 8a). Local throw minima on minor faults also correspond to abrupt changes in

298 the strike, again suggesting a history of fault linkage via segment linkage (Figure 6a). 


\subsection{Rift evolution}

301 In order to determine the growth of the fault array, we now quantify the activity of individual

302 fault systems through the use of isochron maps and throw backstripping.

\subsubsection{Isochron analysis}

Within the earliest resolvable time period, SU1 (from 208.5 to $201.3 \mathrm{Ma}$; i.e. capturing fault activity during the first 7.2 Myrs of rifting), we observe across-fault thickening ( 100 ms TWT) on all major faults (F1-F3; Fig 9a). These fault-controlled depocenters span the entire presentday fault trace length, indicating that major faults had already reached their near-final length

309 during the first 7.2 Myr of the $25.5 \mathrm{Myr}$ rift history (i.e. only $8 \%$ of the total rift duration).

310 Thick (up to $200 \mathrm{~ms}$ TWT or $225 \mathrm{~m}$ ), mound-shaped features are present in the hanging walls of

311 F1, F3-a and F3-b, which we interpret as the deposition of fault scarp-derived talus (Fig 9a)

312 (Bilal et al., 2019; Barrett et al., 2020). Fault scarp-derived deposits provide further evidence that

313 the faults were active during this period. These deposits also suggest that fault slip rates outpaced 314 sediment accumulation rates, and that at-surface relief formed which was then eroded.

315 Thickness variations in SU2 (Figure 9b) show that fault-controlled depocenters persisted 316 adjacent to the major fault systems F1-F3 (from 201.3 to 163.5 Mya; i.e. capturing fault activity 317 during the subsequent 37.5 Myrs of rifting). SU2 depocenters are wider (normal to fault strike) 318 than those in SU1, and show a greater thickness increase up to $3.5 \mathrm{~km}$ away from the fault, 319 indicating increased hanging wall flexure (Fig 9b). SU2 is thickest in the middle of the 320 depocenters adjacent to F3-a and F3-b ( $<170 \mathrm{~ms}$ TWT) instead of immediately adjacent to the 321 bounding faults, which we attribute to the underlying scarp-derived sedimentation in SU1 
322 leading to an apparent reduction in the thickness of deposits in SU2 (Fig 9b, Fig 5). Although

323 there is an overall thickness increase across both F3-a and F3-b ( 120 ms TWT), high thickness

324 variations (up to $220 \mathrm{~ms}$ TWT) are distinct across F3-a and F3-b, separately indicating that the

325 fault segments were soft-linked and separated by a relay zone (Fig 9b). Thickness variations also

326 suggest that F2-a and F2-c segments were active during the SU2 time interval, but a lack of

327 thickness changes in association with F2-b suggest that the F2 system was not hard-linked at this 328 time (Figure 9b).

329 Within SU3 (from 180 to 143 Mya; i.e. capturing fault activity during the subsequent 37

330 Myrs of rifting) we observe a thickness increase of $100 \mathrm{~ms}$ TWT across all segments of F2. This

331 is in contrast to activity within SU2, where no thickness changes occurred across the faults

332 central segment (F2-b), indicating that by 37 Myrs after the onset of rifting, F2 had hard-linked

333 to form a through-going system (Fig 9c). Additionally, thickening across both F3-a and F3-b

334 segments suggest that F3 was now acting as a single, hard-linked fault system that was

335 principally growing via the accumulation of displacement at the expense of lengthening (Figure

336 9c). In summary, F2 and F3 had grown to the maximum lengths after only $33 \%$ of the total rift

337 duration, achieving this by segment linkage and relay breaching. This style of growth resulted in 338 the development of abandoned splays in their hanging wall.

339 SU4 (from 143 to 141 Mya; i.e. capturing fault activity during the subsequent 2 Myrs of 340 rifting) shows a significant thickness increase across F2, indicating this major structure was 341 active at this time. SU5 (from 141 to 138 Mya; i.e. capturing fault activity during the subsequent 3423 Myrs of rifting) shows no thickness variations across F1 and F2, suggesting that these

343 structures were inactive by this time (Fig 9e). F3-a also became inactive as evidenced by

344 constant across-fault thickness of SU5. In contrast, the southern part of the fault system remained 
345 active (F3-c and F3-d), defining a relatively wide ( $\sim 4 \mathrm{~km}$ across strike) depocenter. SU6 (from

346138 to 123 Mya; i.e. capturing fault activity during the subsequent 15 Myrs of rifting) shows that

347 nearly all the northern faults were inactive during this time, as only the southern segments of F2

348 and F3 are associated with thickness variations. However, as these variations appear broad and

349 regional, occurring on a length-scale larger than individual faults (Figure 9f), and given that the

350 timing of deposition of SU6 coincides with a period of widespread regional subsidence along the 351 margin (Hocking, 1987; Driscoll and Karner, 1998), we infer that F3-c, F3-d, F2-b, F2-c may be

352 less active than the spatially related thickness changes suggest.

\subsubsection{Fault throw backstripping}

Isochrons qualitatively reveal that fault lengths were established relatively quickly, as faultcontrolled depocenters nearly span across their entire present-day fault trace lengths within the

357 earliest resolvable slip increments (Fig 9a, 9b). This style of growth is consistent with the 358 constant-length model of fault growth, hence the original rather than modified method is 359 considered more appropriate to backstrip the fault array (e.g. Jackson et al. 2017; see 360 methodology section). H3 is not present across the entire fault array due to footwall erosion (see

361 Figure 7a), therefore backstripping is undertaken to the next resolvable increment $\mathrm{H} 4$ (180 Ma)

362 to view an intermediate stage of array evolution (i.e. at $33 \%$ of the total rift duration). As a result, 363 we can gain a view of rift-related strain after 33\% (Fig 8b) and 100\% of the rift duration (Fig 8a).

364 Our results show that by $33 \%$ of rift history, major faults F1, F2, and F3 had accumulated 365 maximum throws of throws of 261, 181 and $365 \mathrm{~ms}$ TWT (c. 261, 183, $372 \mathrm{~m}$ ) respectively (Fig 3668 b); this is approximately half of the present-day throw. 
Throw accumulation was relatively uniform (averaging $200 \mathrm{~ms}$ TWT) along F1, with a 368 relatively abrupt decrease in throw occurring near a throw minima located at $16.3 \mathrm{~km}$ along the 369 fault (Fig 8 b). This minima corresponds to a small hanging wall splay and a subtle change in 370 fault strike, thus we infer it defines a relay that was breached before this backstripped interval 371 (i.e. before $33 \%$ of the rift duration; Fig 8b, Fig 3b). F1 continues north beyond the seismic 372 dataset, so we cannot tell whether the maximum throw on this structure is located further north; 373 however, extrapolation of the throw gradient at the northern end of F1 suggests this is not the 374 case (Figure 8b). Our results indicate that during the latter part of rifting (33-100\% of the rift 375 duration), F1 accumulated throw near its centre without appreciable lengthening. Our present376 day throw-length plot shows a broadly symmetric, bell-shaped profile, with no strong indication 377 of paleo-segmentation (i.e. displacement minima; Fig 8a).

378 During the initial stage of rifting, F2 exhibited a similar throw distribution as F1, in that 379 throw (average of $130 \mathrm{~ms}$ TWT) was fairly evenly distributed along its constituent segments (F2380 a, F2-b and F2-d; Fig 8b). The throw minima between F2-a and F2-b suggests that these 381 segments were not geometrically linked at this time. Instead, F2-b develops alongside two small 382 hangingwall splays (pink and brown in Fig 8b). At this time, a small splay (purple in Fig. 8b; see 383 Figure 3 for corresponding map) appears to be kinematically interacting with fault segments F2-c 384 and F2-d, given they together define a throw profile that shows a gradual southward increase in 385 throw (Figure 8b). However, the purple splay and F2-d appear to have been abandoned during 386 the latter phase of rifting (33-100\% of rift duration); instead, F2-c gained significant throw (from $387 \sim 80$ to $330 \mathrm{~ms}$ TWT) and hard-linked with F2 as rifting continues (Figure 8). During the latter 388 phase of rifting, F2-b also accumulated a significant amount of displacement (up to $550 \mathrm{~ms}$ 
TWT) to produce the relatively symmetric, bell-shaped throw profile that presently characterises

$390 \quad$ F2 (Fig 8a).

Backstripping of F3 reveals that during the initial stage of rifting, a series of throw

393 F3 still displays a generally symmetric throw profile, its constituent segments are defined by a

394 rather irregular, asymmetric throw profile (Fig 8b). Throw minima (e.g. between F3-a and F3-b)

395 indicate relay zones that was breached prior to this time-step (Fig 8b). By comparing the throw

396 distribution after c. $33 \%$ of the rift history with that presently observed (Figure $8 \mathrm{a}$ ), our results

397 show that during the last $67 \%$ of rift history, the asymmetric and irregular profile of fault system

398 F3 evolved to have a symmetric, bell-shaped profile, with the throw maxima migrating towards

399 the present centre of the fault.

400 Backstripping of minor faults show that fault lengths and throw distribution remained

401 relatively similar during the latter $67 \%$ of the rift history (Fig 8). A number of minor faults

402 appeared to have died-out before the deposition of H4 (180 Ma; Top Murat Siltstone); however,

403 ductile or so-called continuous deformation, make offset difficult to determine at H4. Our

404 interpretation that the minor faults became inactive $<28.5 \mathrm{Myr}$ into the rift event is supported by

405 isochron data, which shows that post-SU2 units do not thicken across them, as well as seismic

406 cross-section evidence that show minor fault tipping-out below H4.

407

408 5. DISCUSSION

$409 \quad$ Timescales of fault growth

410 Our results clearly demonstrate that many of the fault's established their near-final length

411 relatively early in the ca. 85.5 Myr rift history. Throw backstripping quantitatively shows that for 
412 many of the faults, their lengths were essentially fixed after only ca. $33 \%$ of the total rift duration

413 (Fig 8); isochron analysis suggest that fault length establishment may have occurred after as little 414 as $8 \%$ of the total rift duration (Fig 9a). This duration is similar to that documented by Walsh et 415 al., (2002), Jackson et al., (2017), and Rotevatn et al., (2019), who show that faults typically 416 establish their near-final lengths within c. $30 \%$ of their total growth history. Our results show 417 that this early stage of fault lengthening could be even shorter (i.e. 8\%). Whereas current models 418 of fault growth typically focus on the development of the largest fault systems within a given 419 region, we note that some of the minor, antithetic faults located between the larger fault systems, 420 are relatively long (i.e. $>20 \mathrm{~km})$ with low displacements $(<30 \mathrm{~m})$. Although we cannot directly 421 establish if these structures were lengthening and/or accumulating displacement immediately 422 prior to their death, observations of their long trace lengths, paleo-segmentation on time-structure 423 maps (Fig 6), thickness variations from isochrons (Fig 9) and throw minima from throw

424 backstripping (Fig 8), suggest that prior to becoming inactive, the majority of growth was 425 occupied by fault lengthening via segment linkage. We suspect that these long, low-displacement 426 faults may be 'fossilised' in their early stages, providing a snapshot of fault development before 427 localisation and displacement accrual - we discuss this later in the context of our updated model. 428 The last c. $67 \%$ (and possibly up to c. $92 \%$ ) of the $85.5 \mathrm{Myr}$ rift history was characterised by 429 strain localisation and displacement accumulation on the major fault systems (F1-F3). Strain 430 localisation onto larger faults that are ultimately active for longer than smaller faults is also seen 431 in the Inner Moray Firth, North Sea (Nicol et al., 1997; Walsh et al., 2003), and the Timor Sea, 432 NW Shelf of Australia (Meyer et al., 2002), and in numerical (e.g. Cowie et al., 1995; Cowie, 433 1998; Gupta et al., 1998; Naliboff et al., 2020) and physical models (e.g. Ackermann et al., 2002; 434 Mansfield and Cartwright, 2001). Our results demonstrate that the pattern of displacement 
435 accumulation and/or localisation itself is not straightforward, due to complex fault interactions

436 that result in relay breaching and associated splay abandonment (e.g. Fig 9). Isochrons and throw

437 backstripping reveal a distributed fault array that is initially composed of fault systems with

438 multiple displacement maxima and minima. Detailed backstripping analyses show that in the

439 early stages of fault development, fault segments exhibited profiles that were broadly symmetric

440 (i.e. throw was greatest at the fault centres and decreases towards their tips). At the end of rifting

441 (captured by present day geometry), throw profiles of fault systems are also symmetric.

442 However, at an intermediate stage of rifting (33\% of total rift duration; Figure $8 \mathrm{~b}$ ), while fault

443 segments are symmetric, the overall fault system in which they are contained exhibited an

444 irregular, asymmetric throw profile. At this stage of rifting, we observe multiple examples of

445 splay abandonment (e.g. F2-c) related to strain localisation onto more optimally positioned fault

446 segments that lie outside of stress shadows (e.g. F2-b). The along-strike migration of maximum

447 slip at this stage may be important when trying to understand multi-fault ruptures that may occur

448 on previously unrecognised faults, producing larger-than-expected earthquakes (e.g. Wesnousky,

449 1986; Leeder et al., 1991; Goldsworthy and Jackson, 2000; Gupta and Scholz, 2000; Hamling et

450 al., 2017). Our results suggest that interactions between faults can be better understood through

451 changes in fault geometry as an array evolves; this may allow for better predictability of

452 earthquake recurrences in seismic hazard analysis, where a somewhat random Poisson-based

453 process may be used (e.g. Reiter, 1990; Main, 1996; Mildon et al., 2019; Sgambato et al., 2020).

\section{Fault growth trajectory using throw-length relationships}

456 Figure 10 shows our new fault throw-length data for all 150 faults mapped in the Thebe

457 fault array, relative to previously collected D-L data. Note that, in this plot, we have converted 
458 our throw data in ms TWT to displacement in metres, using an average dip of $60^{\circ}$ and borehole-

459 derived time-depth relationships (see section 3.1). On a log-log scale, our data approximately

460 follow a linear trend (i.e. $n=1$ ) across almost three orders of magnitude; this is similar to other

461 global D-L scaling relationships for normal faults (e.g. Watterson, 1986; Walsh and Watterson,

462 1988; Marrett and Allmendinger, 1991; Cowie and Scholz, 1992) (Fig 10). Our data are coloured

463 by dip direction; blue-coloured faults are broadly east-dipping and red-coloured faults are

464 broadly west-dipping (see Fig 7). We observe that, whereas all faults abide by a broadly similar

465 linear scaling relationship $(\mathrm{n}=1)$, the major west-dipping (red-coloured) faults are presently

466 somewhat 'over-displaced' $(\mathrm{c} \sim 0.1)$ relative to the smaller, antithetic, east-dipping faults (c $\sim$

467 0.01) (Fig 10). Most of the over-displaced faults are abandoned splays, left behind in the hanging

468 walls of fault systems after relay breaching and segment linkage. These faults exhibit very short

469 trace lengths but high throws. In contrast to over-displacement, under-displaced faults may be

470 indicative of interpreting faults as systems instead of segments. For example, one fault segment

471 F3-a exhibits a displacement-length ratio of 0.06 , but the entire fault system in which it is

472 contained (i.e. F3) is $46 \mathrm{~km}$ long and has a throw of $656 \mathrm{~ms}$ TWT (c. $858 \mathrm{~m}$ in displacement; Fig

473 8a). This gives a lower D-L ratio of 0.02 (Fig 10), demonstrating that D-L (and T-L) ratios are

474 higher for individual fault segments than systems, although both still plot within the scatter

475 observed in global range D-L data (Fig 10). Similar observations are noted by Peacock and

476 Sanderson (1991) and Roberts and Michetti (2004), highlighting how mixing the analysis of fault

477 segments (e.g. Meyer et al., 2002; Roberts et al., 2004) and/or fault systems (e.g. McLeod et al.,

478 2000) may explain the range of scatter already seen in D-L profiles.

479 Fault length and displacement measurements for the present-day fault array (Fig 8a),

480 coupled with the reconstructed fault array at c. $33 \%$ of the total rift duration (Fig 8b), allow us to 
481 define how D-L relationships have changed over the last c. 67\% (57 Myr) of rift history. Our

482 time-constrained displacement-length relationships reveal either: i) a vertical growth line,

483 indicating that the fault accumulated displacement without lengthening (i.e. the constant fault

484 growth model; Walsh et al., 2003; Nicol et al., 2005; Jackson and Rotevatn, 2013), or; ii) a static

485 point, indicating that the faults was inactive during the last c. $67 \%$ of rifting (Figure 10 inset).

486 Typically, faults that were inactive were the east-dipping antithetic faults that did not slip post-

$487180 \mathrm{Ma}$ and thus remained 'under-displaced' (Fig 10). Because all the major and minor fault

488 systems dip westward and eastward, respectively, the structures onto which strain was eventually

489 localised must have been set early in rift history (i.e. as early as the first c. $8 \%$ of the total rift

490 duration). This may be attributed to positive stress feedback processes occurring during early

491 array development, whereby shear stress reduction or 'stress shadow zones' inhibit fault growth

492 and the nucleation of new cracks (e.g. Hu and Evans, 1989; Ackermann and Schlische, 1997;

493 Cowie, 1998), and optimally positioned faults form and slip (i.e. faults with across-strike spacing

494 of $12-14 \mathrm{~km})$. Early establishment of the near-final fault lengths reinforces the suggestion that

495 lateral tips of faults are effectively pinned by stress interactions with neighbouring faults (e.g.

496 Burgmann et al., 1994; Willemse et al., 1996; Gupta and Scholz, 2000; Contreras, 2000). We

497 propose that distributed faulting, principally characterized by fault lengthening, occurs until a

498 given rock volume is 'strain saturated', as predicted by numerical and physical models (e.g.

499 Cowie and Scholz 1992b; Cowie et al., 1995; Wu and Pollard, 1995; Ackermann et al., 2001).

$500 \quad$ Our observation that minor (E- dipping) faults either die early (where blue coloured faults

501 are static points; Fig 10), or grow and still appear relatively under-displaced (where blue faults

502 have a vertical trajectory that is relatively under-displaced; Fig 10) relative to larger faults onto

503 which strain is subsequently localised (with higher displacement of red faults; Fig 10), has only 
504 been revealed from studying a complete fault array. Considering our data spans nearly three

505 orders of magnitude, and given that the 150 faults formed in broadly similar rock types in the

506 same stress regime, this implies that some of the scatter seen in D-L plots may simply be related

507 to fault maturity and not only from limitations inherent to data collection (e.g. Kim and

508 Sanderson, 2005) and/or differences in rock type and stress regime (e.g. Cowie and Scholz,

509 1992; Gillespie et al., 1992; Scholz et al., 1993).

$510 \quad$ Our findings illustrate the importance of collecting data from entire fault arrays

511 developed over large areas if we hope to determine how normal faults grow. Datasets that allow

512 inspection of only a small part of the rift (e.g. small-scale field-based studies), or analysis of

513 faults lacking growth strata, could produce D-L relationships that appear anomalous (i.e.

514 relatively under- or over-displaced) simply due to fault maturity (i.e. the datasets sample only the

515 very young or old faults). Taking the trendline of datasets may produce an exponent value $n$ that

516 may not be representative of geometrical fault scaling relationships. We suspect that this may be

517 why the true value of $n$ is contested (e.g. Watterson, 1988; Marrett and Allmendinger, 1991;

518 Gillespie et al., 1992; Cowie and Scholz, 1992; Clark and Cox, 1995; Dawers and Anders, 1995;

519 Soliva et al., 2005; Xu et al., 2006; Torabi et al., 2011). By studying complete fault arrays rather

520 than individual fault systems, we can better understand how faults grow and how continental

521 extension proceeds.

523 A model of strain accommodation as the continental lithosphere stretches: incorporating

524 segment- and system-scale growth

525 Although our study demonstrates that during the last c. $67 \%$ of rifting faults either grew

526 by displacement accumulation or became inactive, the magnitude of displacement accumulation 
527 (i.e. the vertical trajectory on D-L profiles) does not extend outside of the overall scatter

528 observed in global D-L plots (where $\mathrm{c} \sim 0.001$, Figure 10 ). This is important, given that recently

529 proposed fault models (constant-length and hybrid) commonly present growth trajectories only

530 very schematically on D-L plots (e.g. Childs et al., 2017; Rotevatn et al., 2019; Fig 2). Due to the

531 lack of scale on each axes, the constant-length and hybrid models also lack geometric constraint,

532 which D-L profiles provide (i.e. faults cannot, for example, exhibit trace lengths of $10 \mathrm{~km}$ with 1

$533 \mathrm{~m}$ of displacement, as this would plot well below the lower trendline of D-L profiles). However,

534 current literature has frequently superimposed the schematic model trajectories onto global D-L

535 data, in turn implying that faults that grow (or grew) via the constant-length and hybrid model

536 apparently lie well outside of the known D-L scaling relationships. We suspect that many

537 observations from ancient (inactive) and modern (active) extensional settings that endorse the

538 constant-length model (e.g. Meyer et al., 2002; Tvedt et al., 2016; Jackson et al., 2017; Rotevatn

539 et al., 2019) infact still lie within the bounds of our proposed geometrical constraint, as our

540 results from offshore Australia show (Figure 10).

541 We propose a new model for how fault systems grow within an array, where faults

542 ultimately scale by a linear relationship in $\log -\log$ space $(n=1)$, but grow by alternating periods

543 of lengthening and localisation, thereby producing a more step-like growth trajectory in D-L

544 space than previously proposed (Fig 11). First, faults initiate as numerous, isolated segments

545 (Stage 1 in Fig 11; e.g. Gawthorpe and Leeder, 1993). Fault lengthening via segment linkage

546 occurs until a small rock volume (e.g. a mechanical layer of rock, which could at the largest scale

547 represent the seismogenic crust) is saturated with faults with relatively little displacement. These

548 early faults appear 'under-displaced' when viewed on D-L plots (2; Fig 11). Once the rock

549 volume is sufficiently saturated with fault trace lengths defining the overall pattern of the fault 
550 network, optimally positioned faults (i.e. those that receive positive stress feedback from

551 adjacent structures) then accrue displacement, whereas faults in stress shadow zones remain

552 inactive and ultimately die (3; Fig 11). This phase of fault localisation and displacement

553 accumulation produces a vertical growth trajectory on D-L plots, where active faults move

554 vertically up until the upper scaling limit (approximately where $\mathrm{c}=0.1$ ). Fault that are not

555 optimally positioned become inactive faults and die along the vertical trajectory, leaving a

556 vertical spread of points. At this point, stress feedback mechanisms cause the fault array to be

557 fully mechanically interacting, essentially inhibiting further fault interaction and growth. To

558 further accommodate strain, the considered rock volume and the overall scale increases (from

559 stage 3 to 4 ; fig 11). During this time the largest fault systems can mechanically interact (e.g.

560 Ackermann et al 2001), acting again as isolated segments during the 'initiation' stage (4; Fig 11).

561 These faults then lengthen, predominantly by segment linkage (5; Fig 11), and then strain

562 localises onto optimally spaced zones, producing more widely spaced major faults (i.e. red fault

563 segment; Fig 11). Faults located in stress shadow zones become inactive, appearing relatively

564 under-displaced in D-L space (i.e. the green segment; Fig 11).

565 Our model includes aspects of the isolated and constant-length fault models. This is

566 important because in the absence of data that truly constrains the temporal evolution of fault

567 arrays and their constituent segments and systems, faults may appear to follow a sloping, linear

568 trajectory, thereby endorsing the isolated model. The hybrid and constant-length models are also

569 supported given that the final increment of fault growth, which in our study accounts for at least

570 c. $67 \%$ of the rift history, is defined solely by displacement accumulation. Our fault growth

571 model builds on this premise, however, by considering that faults systems interact as part of an

572 array and are not kinematically or mechanically isolated (Fig 11). 
Our suggested model inevitably leads to a lot of scatter in D-L profiles from the onset of

574 extension, with this outcome indicating that the natural variability in D-L relationships may be

575 an even bigger consequence of fault growth than previously suggested (e.g. Peacock and

576 Sanderson 1991; Cartwright et al., 1995; Peacock and Sanderson, 1996). We suggest that the

577 'inflection point' between fault lengthening and displacement accumulation, bounded at D-L

578 scaling trendlines (c, Fig 11), is controlled by the physical (e.g. mechanical strength, effective

579 elastic thickness) characteristics of the region undergoing strain and, more specially, relates to

580 layer thickness (cf. Ackermann et al., 2002) and areal extent, as this determines a 'saturation'

581 point of fault lengths and displacements. Studies proposing a linear correlation between layer

582 thickness and fault spacing are consistent with our updated model of fault growth, as this this

583 relationship is largely driven by stress feedback mechanisms (Soliva and Benedicto, 2005; Soliva

584 et al., 2006). Due to many natural mechanical heterogeneities in the subsurface, the 'inflection'

585 transition may occur at any point in scale and account for the more subtle changes in growth

586 trajectory path variability that may be lost in log-log space (Rotevatn et al., 2019). Further

587 decrypting the 'natural' variability of global D-L plots by unravelling fault growth trajectories

588 may allow us to better predict certain structural and mechanical properties, such as crustal

589 thickness or mechanically confined layers in data-poor regions.

590 From our model, we are able to characterise the scaling properties and consider the

591 growth stage of active and ancient, natural fault arrays. Fault populations that sit near the lower

592 D-L boundary, where $\mathrm{c}=0.01$, exhibit distributed faulting, are seen in the Central Afar and on

593 the Asal Ghoubbet faults in East Africa (c 0.012 in Manghietti et al., 2015). In contrast, fault

594 populations that lie closer to the upper D/L boundary $(\mathrm{c}=0.1)$ may be characterised by more

595 localised faulting, similar to that seen in fault populations imaged in seismic reflection data (e.g. 
northern North Sea; McLeod et al., 2000, NW Shelf of Australia; Black et al., 2017). 3D seismic

597 reflection surveys will often image now-inactive, ancient rifts that have proceeded through a

598 phase of strain localisation. Therefore, typical fault system-scale studies may only capture the

599 most mature faults that have accrued the largest amounts of displacement, potentially leading to

600 an erroneous endorsement of the constant-length model. Conversely, studies from active rifts

601 may be biased toward fault populations with lower c values, as immature faults in their early

602 phase of development may be more readily captured by these datasets.

603 Resolving whether length establishment occurs within, for example, a few tens of

604 thousands to a few million years is difficult with seismic reflection data from ancient rifts, given

605 that the limited spatial and temporal resolution of seismic data at depth; it may thus be difficult

606 to learn more about the fault lengthening stage from solely the kinematic analysis of seismic

607 reflection data that image ancient basins. We suggest that future studies should focus on active,

608 over-filled, shallowly buried (and thus seismically well-imaged) rifts (e.g. the Whakatane rift,

609 New Zealand; Taylor et al., 2004), but 3D seismic data rather than grids of 2D data will really be

610 required. Additionally, numerical and physical models may be able to test our hypothesis by

611 constraining fault growth through global scaling relationships to investigate the inflection point

612 of fault growth trajectories observed in D-L space.

613

614 6. CONCLUSIONS

615 - The timescales over which a fault array evolves have previously not been well

616 constrained, due to a lack of dynamic, kinematic data. 
- To fill this gap, we studied an extensive fault array $\left(1200 \mathrm{~km}^{2}\right)$ in the Exmouth Plateau, NW Australia and characterised 150 seismically resolvable faults using displacement-

619 length relationships.

620 - Isochron maps reveal that within the earliest resolvable slip increment of 7.2 Myrs (out of 621 an overall duration of $85.5 \mathrm{Myrs}$ ) the majority of fault lengths have already been 622 established.

623 - Fault displacement backstripping to 28.5 Myrs (33\% of total rift duration) shows that the 624 fault array was characterised with distributed faulting. Backstripping reveals along-strike 625 slip migration through time to produce symmetric fault systems. Throw minima suggest 626 previous segmentation and relay breaching.

627 - Our results allow us to view the last growth trajectory (representing the last $67 \%$ of total 628 rift duration) on D-L plots. Faults undergo varying amounts of displacement accrual (i.e. 629 the constant length model). Less (to no) displacement is accrued on faults in stress $630 \quad$ shadow zones.

631 - We propose that fault length and displacement scale linearly $(n=1)$ but grow via 632 alternating phases of lengthening and displacement accrual. Our model is largely based 633 on stress feedback mechanisms driven by layer/crustal thickness, which produce 634 'inflection' points in D-L space.

635 - Inactive faults located in stress shadow zones contribute towards the large amount of 636 global displacement-length scatter due to differences in fault maturity. As the scatter 637 may be inherent to fault growth, D-L relationships may help us to differentiate fault $638 \quad$ characteristics in ancient and modern rifts. 


\section{ACKNOWLEDGEMENTS}

641 This manuscript contains work conducted during a $\mathrm{PhD}$ study undertaken as part of the Natural

642 Environment Research Council (NERC) Centre for Doctoral Training (CDT) in Oil \& Gas

$643[\mathrm{NE} / \mathrm{R} 01051 \mathrm{X} / 1]$. We are grateful for the provision of publicly accessible subsurface data by

644 Geoscience Australia - the Thebe 3D dataset can be downloaded from the NOPIMS data

645 repository website: https://nopims.dmp.wa.gov.au/nopims. We thank Geoteric for downloading

646 and transferring the dataset for us, as well as providing access to their software. Schlumberger

647 are thanked for the donation of Petrel software licences.

\section{FIGURE CAPTIONS}

649 Figure 1. Fault array evolution, modified after Gawthorpe and Leeder, (2000). Faults grow from 650 an initiation stage (A) with isolated, short (20-10 km) and low-displacement fault segments into 651 a period of interaction and linkage (B), and finally strain localises onto a few long $(>10 \mathrm{~km})$,

652 high displacement 'through-going' fault zones (C). Typically, studies investigating fault growth 653 measure the geometry of fault systems when they have reached (C).

654 Figure 2. Global displacement-length (D-L) data of normal faults. D-L relationships are 655 presented in log-log space, therefore the line of best fit results in the scaling exponent, n. Faults 656 may grow via the isolated where increases in displacement and length occur sympathetically, 657 producing the green growth trajectory; or the constant-length model where the final length is 658 established early in slip history, prior to accumulation of significant displacement, producing the 659 blue trajectory.

660 Figure 3. The location of our study area: (a) Location of the Thebe field seismic dataset within 661 the Exmouth Plateau, North Carnarvon Basin, North West Shelf of Australia. Sub-basin 662 boundaries are taken from Geoscience Australia. The main structural NE- trends in Fig 3b are 
663 from Bilal et al. 2019; and (b) The main structural elements of the Thebe dataset. Major fault

664 systems are labelled in colour, correlating to their respective throw-profiles in Figure 8. Minor

665 faults are coloured in light grey. Wells Thebe-1 and Thebe-2 are shown.

666 Figure 4. Horizons and their respective formation ages. H1 and H10 are pre-rift and post-rift

667 reflectors, whereas $\mathrm{H} 2$ - H9 define the syn-kinematic unit of the study area. H4, H5 and H6 do

668 not contain biostratigraphic ages, therefore age is inferred through the assumption of constant

669 sedimentation. Our different methodologies to understand rift evolution are resolved to different

670 stages in time, which has been demonstrated on the right.

671 Figure 5. Cross section of inline 1524 (location shown on Figure 3b): (a) Without interpretation;

672 and (b) With interpretation and annotation highlighting the main structural features of the overall

673 study area.

674 Figure 6. Time-surface maps (ms TWT) showing the present day structure of the dataset. Faults

675 at each successive interval are mapped using a variance attribute overlay for higher confidence.

676 Figure 7. Dip direction of the fault array. The rose diagram shows the average strike azimuth

677 and dip direction per fault segment. The rose diagram is split into two halves, whereby the blue

678 coloured faults are east dipping, and the red coloured faults are west dipping.

679 Figure 8. Throw length profiles (segments coloured by Fig 3b) and their map view throw

680 distribution, for (a) The present day fault array, i.e. the final product of rift history; and (b) The

681 reconstructed, backstripped fault array, where faults are backstripped to 28.5 Myrs (H4; Top

682 Murat).

683 Figure 9. Isochron maps showing thickness changes between syn-depositional horizons. The

684 syn-rift unit is divided into six, labelled as SU1-SU6. 
685 Figure 10. Our results plotted against global displacement-length data in grey. Our data is

686 coloured by the dip map (see Figure 7) whereby blue-coloured faults are east dipping, and red-

687 coloured faults are red dipping. Our results were measured in throw, but we have converted our

688 values into displacement by assuming an average dip of 60 (see supplementary table for raw

689 values). The inset shows the last $67 \%$ of rift history, as we connect our present-day values of

690 fault geometry with their respective backstripped values.

691 Figure 11. Our new proposed fault growth model, where the fault trajectory shows growth via

692 alternating phases of fault lengthening (producing a near horizontal trajectory) and fault

693 displacement (producing a near vertical trajectory). Stage 1, 2 and 3 are examples of initiation,

694 linkage and localisation over a smaller region. Faults initiate as small numerous fault segments

695 (1), then lengthen via segment linkage until the rock volume is sufficiently saturated, producing

696 relatively under-displaced D-L values (2), displacement accrues on optimally located and spaced

697 faults (3). Once the smaller region is saturated by fault lengths and displacement, the considered

698 region increases, allowing the fault array to undergo initiation (4), lengthening (5) and

699 localisation (6) again at a larger scale.

700

701

702 DATA AVAILABILITY STATEMENT

703 The data that support the findings of this study are available from the corresponding author upon

704 reasonable request.

705

706 REFERENCES CITED

707 Allmendinger, R.W. and Zapata, T.R., 2000. The footwall ramp of the Subandean decollement, 
northernmost Argentina, from extended correlation of seismic reflection

709 data. Tectonophysics, 321(1), pp.37-55.

710 Anders, M.H. and Schlische, R.W., 1994. Overlapping faults, intrabasin highs, and the growth 711 of normal faults. The Journal of Geology, 102(2), pp.165-179.

712 Bailey, W.R., Walsh, J.J. and Manzocchi, T., 2005. Fault populations, strain distribution and 713 basement fault reactivation in the East Pennines Coalfield, UK. Journal of Structural 714 Geology, 27(5), pp.913-928.

715 Baker, B.H., Mohr, P.A. and Williams, L.A.J., 1972. Geology of the eastern rift system of $716 \quad$ Africa (Vol. 136). Geological Society of America.

717 Barber, P.M., 1988. The Exmouth Plateau deep water frontier: a case history.

718 Bell, R.E., Jackson, C.A.L., Whipp, P.S. and Clements, B., 2014. Strain migration during 719 multiphase extension: Observations from the northern North Sea. Tectonics, 33(10), pp.19367201963.

721 Bell, R.E., McNeill, L.C., Bull, J.M., Henstock, T.J., Collier, R.L. and Leeder, M.R., 2009.

722 Fault architecture, basin structure and evolution of the Gulf of Corinth Rift, central $723 \quad$ Greece. Basin Research, 21(6), pp.824-855.

724 Bilal, A., McClay, K. and Scarselli, N., 2018. Fault-scarp degradation in the central Exmouth 725 Plateau, North West Shelf, Australia. Geological Society, London, Special Publications, 476, $726 \quad$ pp.SP476-11.

727 Black, M., McCormack, K.D., Elders, C. and Robertson, D., 2017. Extensional fault evolution 728 within the Exmouth Sub-basin, North West Shelf, Australia. Marine and Petroleum 729 Geology, 85, pp.301-315.

730 Bosworth, W., 1985. Geometry of propagating continental rifts. Nature, 316(6029), p.625. 
731 Cartwright, J.A., Trudgill, B.D. and Mansfield, C.S., 1995. Fault growth by segment linkage: an 732 explanation for scatter in maximum displacement and trace length data from the Canyonlands 733 Grabens of SE Utah. Journal of Structural Geology, 17(9), pp.1319-1326.

734 Chapman, T.J. and Meneilly, A.W., 1991. The displacement patterns associated with a reverse735 reactivated, normal growth fault. Geological Society, London, Special Publications, 56(1), 736 pp.183-191.

737 Childs, C., Manzocchi, T., Nicol, A., Walsh, J.J., Soden, A.M., Conneally, J.C. and Delogkos, 738 E., 2017. The relationship between normal drag, relay ramp aspect ratio and fault zone 739 structure. Geological Society, London, Special Publications, 439(1), pp.355-372.

740 Childs, C., Nicol, A., Walsh, J.J. and Watterson, J., 2003. The growth and propagation of 741 synsedimentary faults. Journal of Structural geology, 25(4), pp.633-648.

742 Cladouhos, T.T. and Marrett, R., 1996. Are fault growth and linkage models consistent with 743 power-law distributions of fault lengths?. Journal of Structural Geology, 18(2-3), pp.281293.

745 Collettini, C. and Barchi, M.R., 2002. A low-angle normal fault in the Umbria region (Central 746 Italy): a mechanical model for the related microseismicity. Tectonophysics, 359(1-2), pp.97$747 \quad 115$.

748 Cowie, P.A. and Scholz, C.H., 1992. Physical explanation for the displacement-length 749 relationship of faults using a post-yield fracture mechanics model. Journal of Structural $750 \quad$ Geology, 14(10), pp.1133-1148.

751 Cowie, P.A., Gupta, S. and Dawers, N.H., 2000. Implications of fault array evolution for synrift 752 depocentre development: insights from a numerical fault growth model. Basin $753 \quad$ Research, 12(3-4), pp.241-261. 
754 Dawers, N.H. and Underhill, J.R., 2000. The role of fault interaction and linkage in controlling 755 synrift stratigraphic sequences: Late Jurassic, Statfjord East area, northern North Sea. AAPG 756 bulletin, 84(1), pp.45-64.

757 Driscoll, N.W. and Karner, G.D., 1998. Lower crustal extension across the Northern Carnarvon 758 basin, Australia: Evidence for an eastward dipping detachment. Journal of Geophysical 759 Research: Solid Earth, 103(B3), pp.4975-4991.

760 Dutton, D.M. and Trudgill, B.D., 2009. Four-dimensional analysis of the Sembo relay system, 761 offshore Angola: Implications for fault growth in salt-detached settings. $A A P G$ 762 bulletin, 93(6), pp.763-794.

763 Estimates of strain due to brittle faulting: sampling of fault populations. Journal of Structural 764 Geology, 13(6), pp.735-738.10(3), pp.239-247.

765 Exon, N.F., Haq, B.U. and Von Rad, U., 1992. Exmouth Plateau revisited: scientific drilling 766 and geological framework. In Proceedings of the Ocean Drilling Program, Scientific 767 Results (Vol. 122, pp. 3-20). College Station, Tex: Ocean Drilling Program.

768 Gartrell, A.P., 2000. Rheological controls on extensional styles and the structural evolution of 769 the Northern Carnarvon Basin, North West Shelf, Australia. Australian Journal of Earth $770 \quad$ Sciences, $47(2)$, pp.231-244.

771 Gawthorpe, R.L. and Leeder, M.R., 2000. Tectono-sedimentary evolution of active extensional $772 \quad$ basins. Basin Research, 12(3-4), pp.195-218.

773 Gawthorpe, R.L., Jackson, C.A.L., Young, M.J., Sharp, I.R., Moustafa, A.R. and Leppard, 774 C.W., 2003. Normal fault growth, displacement localisation and the evolution of normal fault 775 populations: the Hammam Faraun fault block, Suez rift, Egypt. Journal of Structural 776 Geology, 25(6), pp.883-895. 
777 Gibbons, A.D., Barckhausen, U., Van Den Bogaard, P., Hoernle, K., Werner, R., Whittaker,

778 J.M. and Müller, R.D., 2012. Constraining the Jurassic extent of Greater India: Tectonic

779 evolution of the West Australian margin. Geochemistry, Geophysics, Geosystems, 13(5).

780 Gillespie, P.A., Howard, C.B., Walsh, J.J. and Watterson, J., 1993. Measurement and

781 characterisation of spatial distributions of fractures. Tectonophysics, 226(1-4), pp.113-141.

782 Gupta, S., Cowie, P.A., Dawers, N.H. and Underhill, J.R., 1998. A mechanism to explain rift-

783 basin subsidence and stratigraphic patterns through fault-array evolution. Geology, 26(7),

$784 \quad$ pp.595-598.

785 Gutenberg, B. and Richter, C.F., 1944. Frequency of earthquakes in California. Bulletin of the

786 Seismological Society of America, 34(4), pp.185-188.

787 Hamilton, W., 1987. Mesozoic geology and tectonics of the Big Maria Mountains region,

788 southeastern California. Mesozoic rocks of southern Arizona and adjacent areas: Arizona

789 Geological Society Digest, 18, pp.33-47.

790 Heine, C. and Müller, R.D., 2005. Late Jurassic rifting along the Australian North West Shelf:

791 margin geometry and spreading ridge configuration. Australian Journal of Earth

$792 \quad$ Sciences, 52(1), pp.27-39.

793 Hocking, R.M. and Preston, W.A., 1998. Western Australia: Phanerozoic geology and mineral

794 resources. AGSO Journal of Australian Geology and Geophysics, 17, pp.245-260.

795 Jablonski, D., 1997. Recent advances in the sequence stratigraphy of the Triassic to Lower

796 Cretaceous succession in the Northern Carnarvon Basin, Australia. The APPEA

797 Journal, 37(1), pp.429-454.

798 Jackson, C.A.L. and Rotevatn, A., 2013. 3D seismic analysis of the structure and evolution of a

799 salt-influenced normal fault zone: a test of competing fault growth models. Journal of 
801 Jackson, C.A.L. and Rotevatn, A., 2013. 3D seismic analysis of the structure and evolution of a 802 salt-influenced normal fault zone: a test of competing fault growth models. Journal of $803 \quad$ Structural Geology, 54, pp.215-234.

804 Jackson, C.A.L., Bell, R.E., Rotevatn, A. and Tvedt, A.B., 2017. Techniques to determine the 805 kinematics of synsedimentary normal faults and implications for fault growth 806 models. Geological Society, London, Special Publications, 439(1), pp.187-217.

807 Kanamori, H. and Anderson, D.L., 1975. Theoretical basis of some empirical relations in 808 seismology. Bulletin of the seismological society of America, 65(5), pp.1073-1095.

809 King, G.C. and Sammis, C.G., 1992. The mechanisms of finite brittle strain. Pure and Applied $810 \quad$ Geophysics, 138(4), pp.611-640.

811 Kostrov, V.V., 1974. Seismic moment and energy of earthquakes, and seismic flow of rock. Izv. 812 Acad. Sci. USSR Phys. Solid Earth, 1, pp.23-44.

813 Leeder, M.R. and Jackson, J.A., 1993. The interaction between normal faulting and drainage in 814 active extensional basins, with examples from the western United States and central 815 Greece. Basin research, 5(2), pp.79-102.

816 Logatchev, N.A. and Zorin, Y.A., 1992. Baikal rift zone: structure and 817 geodynamics. Tectonophysics, 208(1-3), pp.273-286.

818 Long, J.J. and Imber, J., 2010. Geometrically coherent continuous deformation in the volume 819 surrounding a seismically imaged normal fault-array. Journal of Structural Geology, 32(2), $820 \quad$ pp.222-234.

821 Longley, I.M., Buessenschuett, C., Clydsdale, L., Cubitt, C.J., Davis, R.C., Johnson, M.K., 822 Marshall, N.M., Murray, A.P., Somerville, R., Spry, T.B. and Thompson, N.B., 2002, 
October. The North West Shelf of Australia—a Woodside perspective. In The Sedimentary Basins of Western Australia 3: Proceedings of the Petroleum Exploration Society of

825 Australia Symposium, Perth (pp. 27-88). Perth: Pet. Explor. Soc. of Aust..

826 Manzocchi, T., Walsh, J.J. and Bailey, W.R., 2009. Population scaling biases in map samples of 827 power-law fault systems. Journal of Structural Geology, 31(12), pp.1612-1626.

828 Marrett, R. and Allmendinger, R.W., 1990. Kinematic analysis of fault-slip data. Journal of 829 structural geology, 12(8), pp.973-986.

830 McCormack, K.D. and McClay, K., 2013, August. Structural architecture of the gorgon 831 platform, North West Shelf, Australia. In The Sedimentary Basins of Western Australia IV:

832 Proceedings of the Petroleum Exploration Society of Australia Symposium, Perth, WA (pp. 1$83324)$.

834 McLeod, A.E., Dawers*, N.H. and Underhill, J.R., 2000. The propagation and linkage of 835 normal faults: insights from the Strathspey-Brent-Statfjord fault array, northern North 836 Sea. Basin Research, 12(3-4), pp.263-284.

837 Metcalfe, I., 2013. Gondwana dispersion and Asian accretion: Tectonic and palaeogeographic 838 evolution of eastern Tethys. Journal of Asian Earth Sciences, 66, pp.1-33.

839 Meyer, V., Nicol, A., Childs, C., Walsh, J.J. and Watterson, J., 2002. Progressive localisation of 840 strain during the evolution of a normal fault population. Journal of Structural $841 \quad$ Geology, 24(8), pp.1215-1231.

842 Molnar, P. and Chen, W.P., 1983. Focal depths and fault plane solutions of earthquakes under 843 the Tibetan plateau. Journal of Geophysical Research: Solid Earth, 88(B2), pp.1180-1196.

844 Morley, C.K., 2002. A tectonic model for the Tertiary evolution of strike-slip faults and rift 845 basins in SE Asia. Tectonophysics, 347(4), pp.189-215. 
846 Nicol, A., Walsh, J., Berryman, K. and Nodder, S., 2005. Growth of a normal fault by the

847 accumulation of slip over millions of years. Journal of Structural Geology, 27(2), pp.327-

$848 \quad 342$.

849 Peacock, D.C.P. and Sanderson, D.J., 1991. Displacements, segment linkage and relay ramps in 850 normal fault zones. Journal of Structural Geology, 13(6), pp.721-733.

851 Petersen, K., Clausen, O.R. and Korstgård, J.A., 1992. Evolution of a salt-related listric growth 852 fault near the D-1 well, block 5605, Danish North Sea: displacement history and salt 853 kinematics. Journal of Structural Geology, 14(5), pp.565-577.

854 Pryer, L.L., Romine, K.K., Loutit, T.S. and Barnes, R.G., 2002. Carnarvon basin architecture 855 and structure defined by the integration of mineral and petroleum exploration tools and 856 techniques. The APPEA Journal, 42(1), pp.287-309.

857 Rotevatn, A., Jackson, C.A.L., Tvedt, A.B., Bell, R.E. and Blækkan, I., 2019. How do normal 858 faults grow?. Journal of Structural Geology, 125, pp.174-184.

859 Rowan, M.G., Hart, B.S., Nelson, S., Flemings, P.B. and Trudgill, B.D., 1998. Three860 dimensional geometry and evolution of a salt-related growth-fault array: Eugene Island 330 861 field, offshore Louisiana, Gulf of Mexico. Marine and petroleum geology, 15(4), pp.309-328.

862 Schlische, R.W., Young, S.S., Ackermann, R.V. and Gupta, A., 1996. Geometry and scaling 863 relations of a population of very small rift-related normal faults. Geology, 24(8), pp.683-686.

864 Scholz, C.H., Dawers, N.H., Yu, J.Z., Anders, M.H. and Cowie, P.A., 1993. Fault growth and 865 fault scaling laws: preliminary results. Journal of Geophysical Research: Solid 866 Earth, 98(B12), pp.21951-21961.

867 Seyitoğlu, G. and Scott, B.C., 1996. Age of the Alaşehir graben (west Turkey) and its tectonic 868 implications. Geological Journal, 31(1), pp.1-11. 
869 Stagg, H.M.J. and Colwell, J.B., 1994. The structural foundations of the Northern Carnarvon

$870 \quad$ Basin.

871 Thorsen, C.E., 1963. Age of growth faulting in southeast Louisiana.

872 Walsh, J.J. and Watterson, J., 1988. Analysis of the relationship between displacements and

873 dimensions of faults. Journal of Structural geology, Marrett, R. and Allmendinger, R.W., $874 \quad 1991$.

875 Walsh, J.J., Childs, C., Imber, J., Manzocchi, T., Watterson, J. and Nell, P.A.R., 2003. Strain

876 localisation and population changes during fault system growth within the Inner Moray Firth,

877 Northern North Sea. Journal of Structural Geology, 25(2), pp.307-315.

878 Walsh, J.J., Nicol, A. and Childs, C., 2002. An alternative model for the growth of

879 faults. Journal of Structural Geology, 24(11), pp.1669-1675.

880 Watterson, J., 1986. Fault dimensions, displacements and growth. Pure and Applied

881 Geophysics, 124(1-2), pp.365-373.

882 Whipp, P.S., Jackson, C.A.L., Gawthorpe, R.L., Dreyer, T. and Quinn, D., 2014. Normal fault 883 array evolution above a reactivated rift fabric; a subsurface example from the northern Horda 884 Platform, Norwegian North Sea. Basin Research, 26(4), pp.523-549. 


\section{A) Initiation}

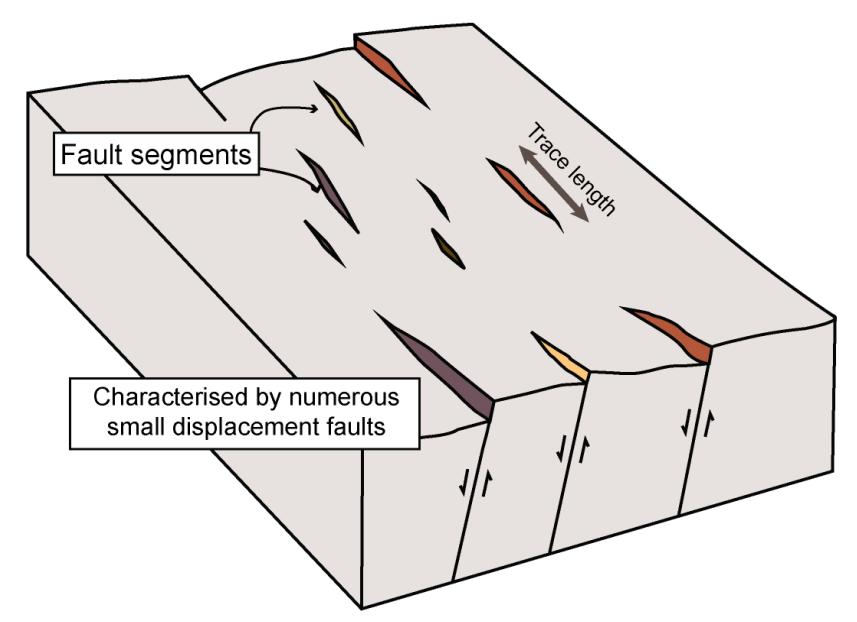

B) Interaction and linkage

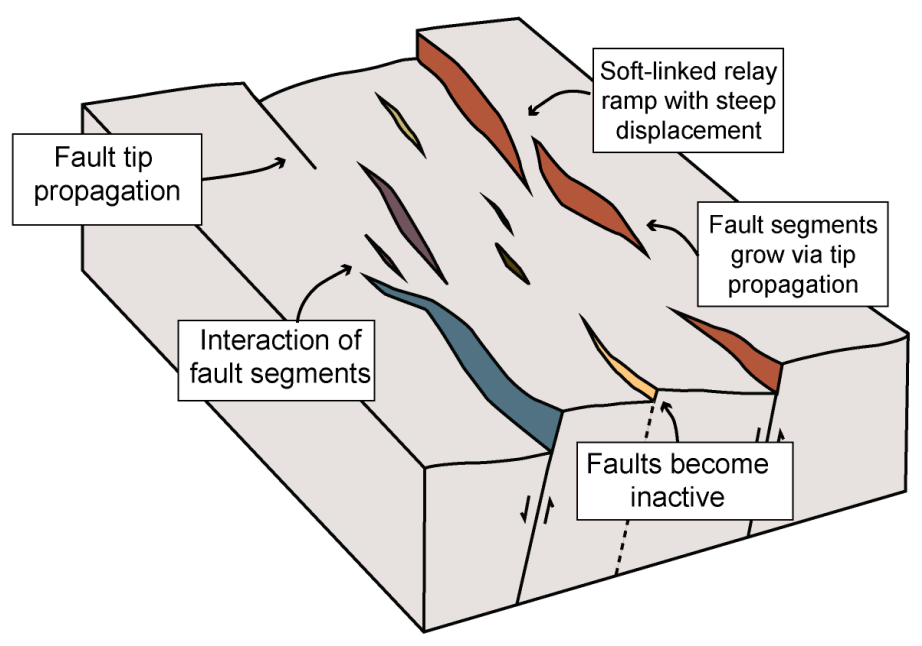

C) Through-going fault zones

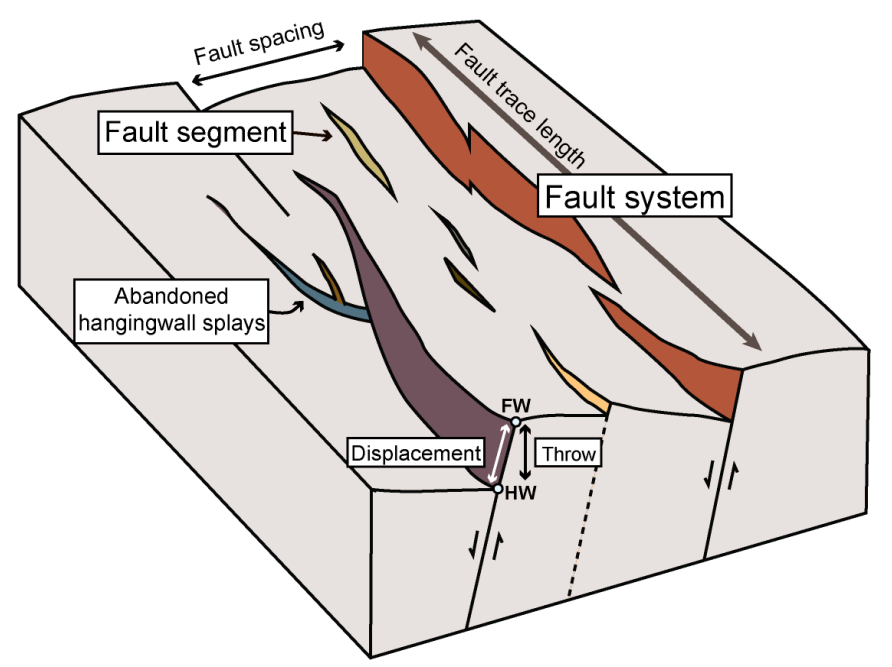

Figure 1. Fault array evolution, modified after Gawthorpe and Leeder (2000). Faults grow from an initiation stage (A) with isolated, short (20-10 km) and low-displacement fault segments into a period of interaction and linkage (B), and finally strain localises onto a few long (>10 km), high displacement 'through-going' fault zones (C). Typically, studies investigating fault growth measure the geometry of fault systems when they have reached (C). 


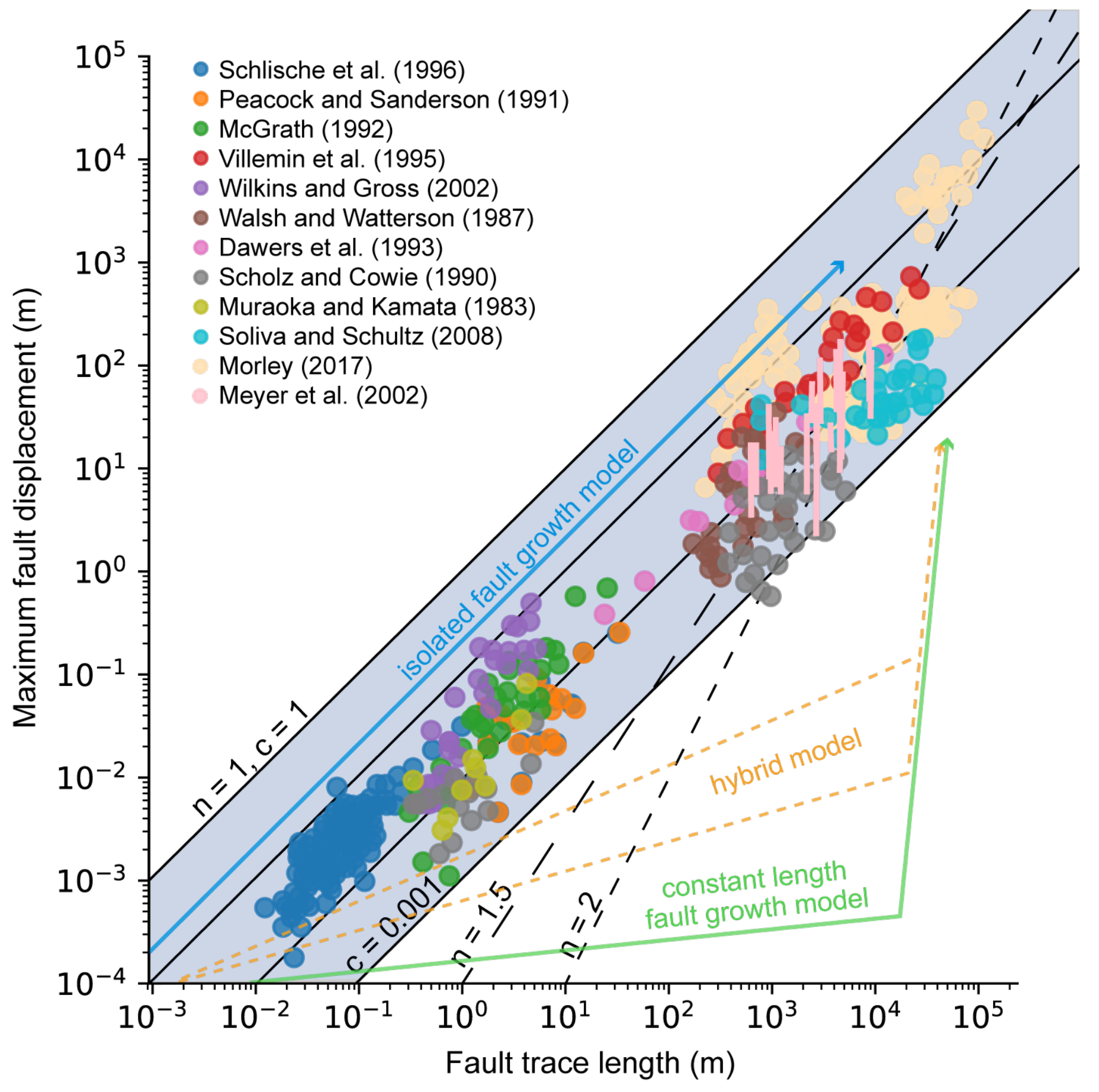

Figure 2. Global displacementlength (D-L) data of normal faults. $D-L$ relationships are presented in log-log space, therefore the line of best fit results in the scaling exponent, n. Faults may grow via the isolated model where increases in displacement and length occur sympathetically, producing the blue growth trajectory; or the constantlength model where the final length is established early in slip history, prior to accumulation of significant displacement, producing the green trajectory. 

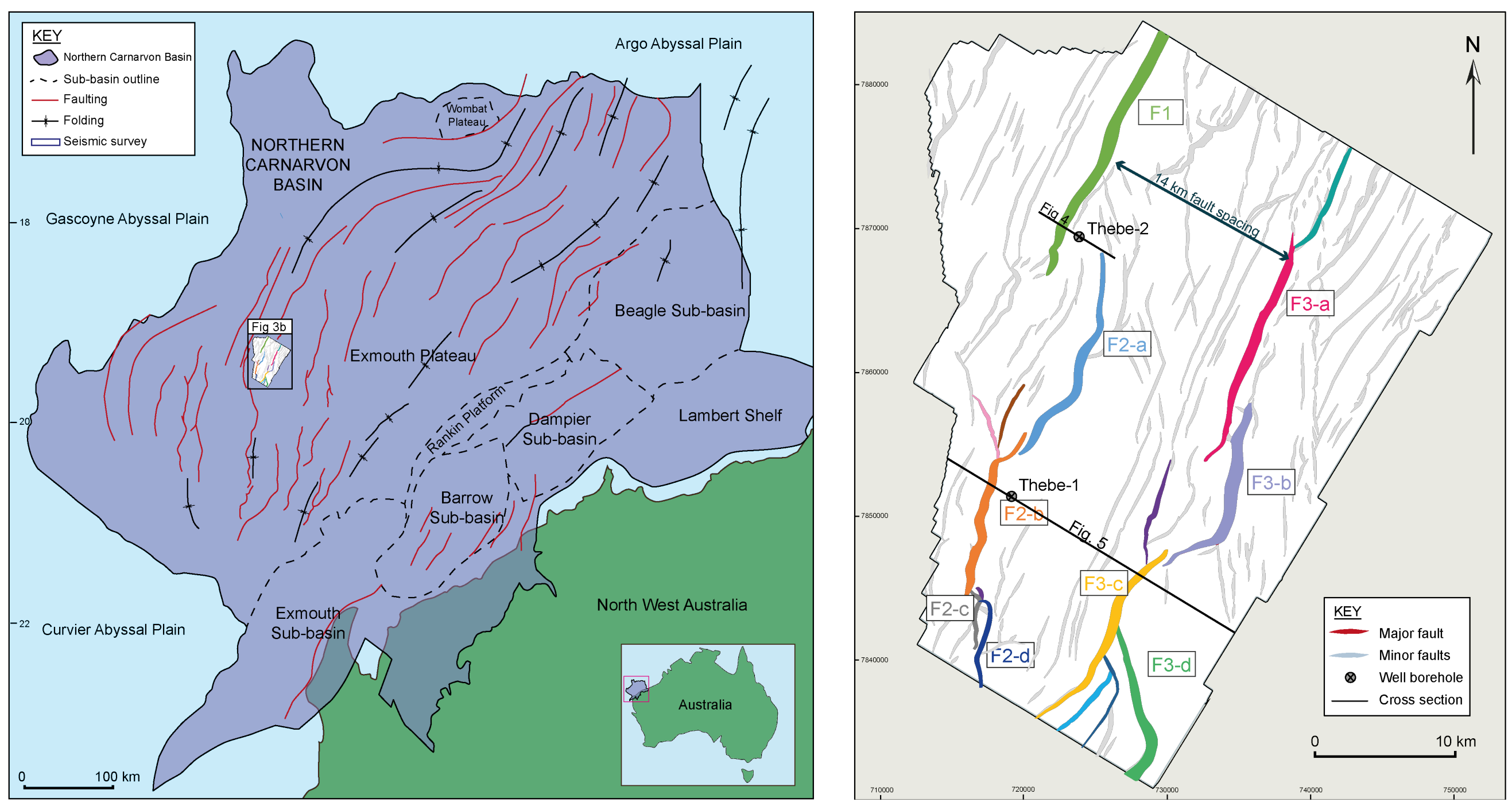

Figure 3. The location of our study area: (a) Location of the Thebe field seismic dataset within the Exmouth Plateau, North Carnarvon Basin, North West Shelf of Australia. Sub-basin boundaries are taken from Geoscience Australia. The main structural NE- trends in Fig $3 \mathrm{~b}$ are from Bilal et al., (2019); and (b) The main structural elements of the Thebe dataset. Major fault systems are labelled in colour, correlating to their respective throw-profiles in Figure 8. Minor faults are coloured in light grey. Wells Thebe-1 and Thebe-2 are shown. 


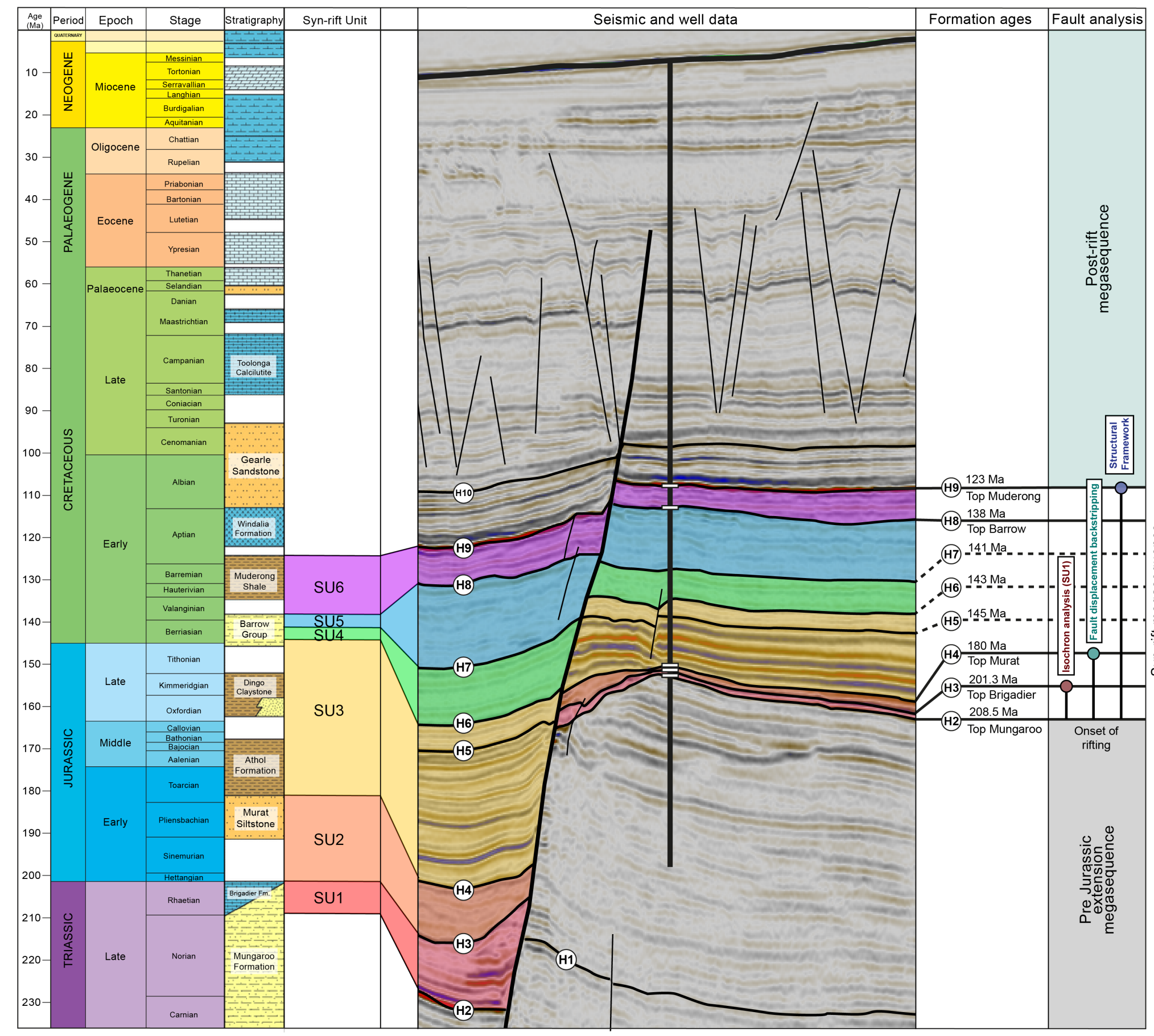

Figure 4. Horizons and their respective formation ages. $\mathrm{H} 1$ and $\mathrm{H} 10$ are pre-rift and postrift reflectors, whereas $\mathrm{H} 2$ - H9 define the synkinematic unit of the study area. $\mathrm{H} 4, \mathrm{H} 5$ and $\mathrm{H} 6$ do not contain biostratigraphic ages, therefore age is inferred through the assumption of constant sedimentation. Various methodologies used to understand rift evolution are resolved to different stages in time, which has been demonstrated on the right. 
Figure 6. Time-surface maps (ms TWT) showing the present day structure of the dataset. Faults at each successive interval are mapped using a variance attribute overlay for higher confidence.
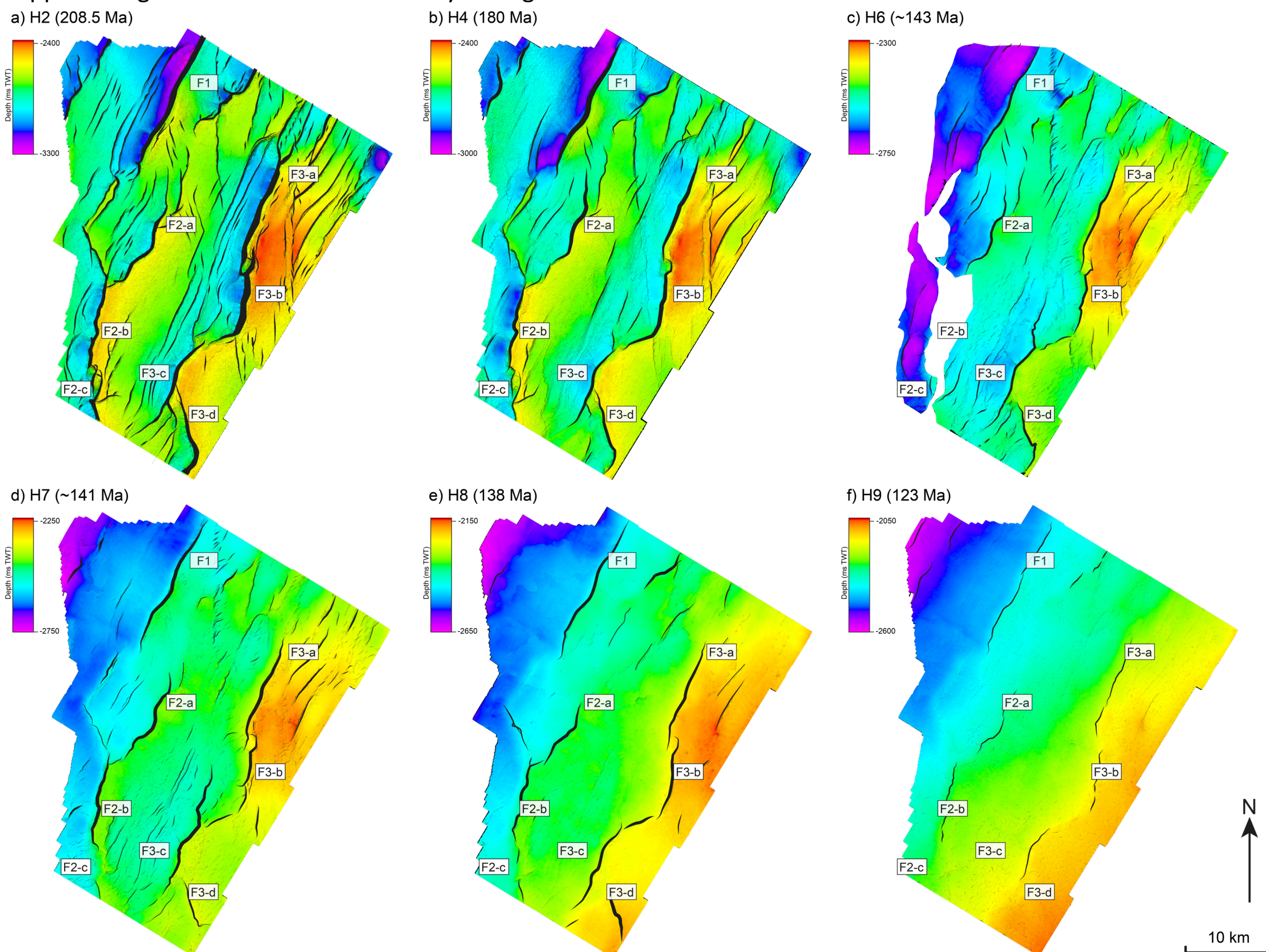
Figure 7. Dip direction of the fault array. The rose diagram shows the average strike azimuth and dip direction per fault segment. The rose diagram is split into two halves, whereby the blue coloured faults are east dipping, and the red coloured faults are west dipping.
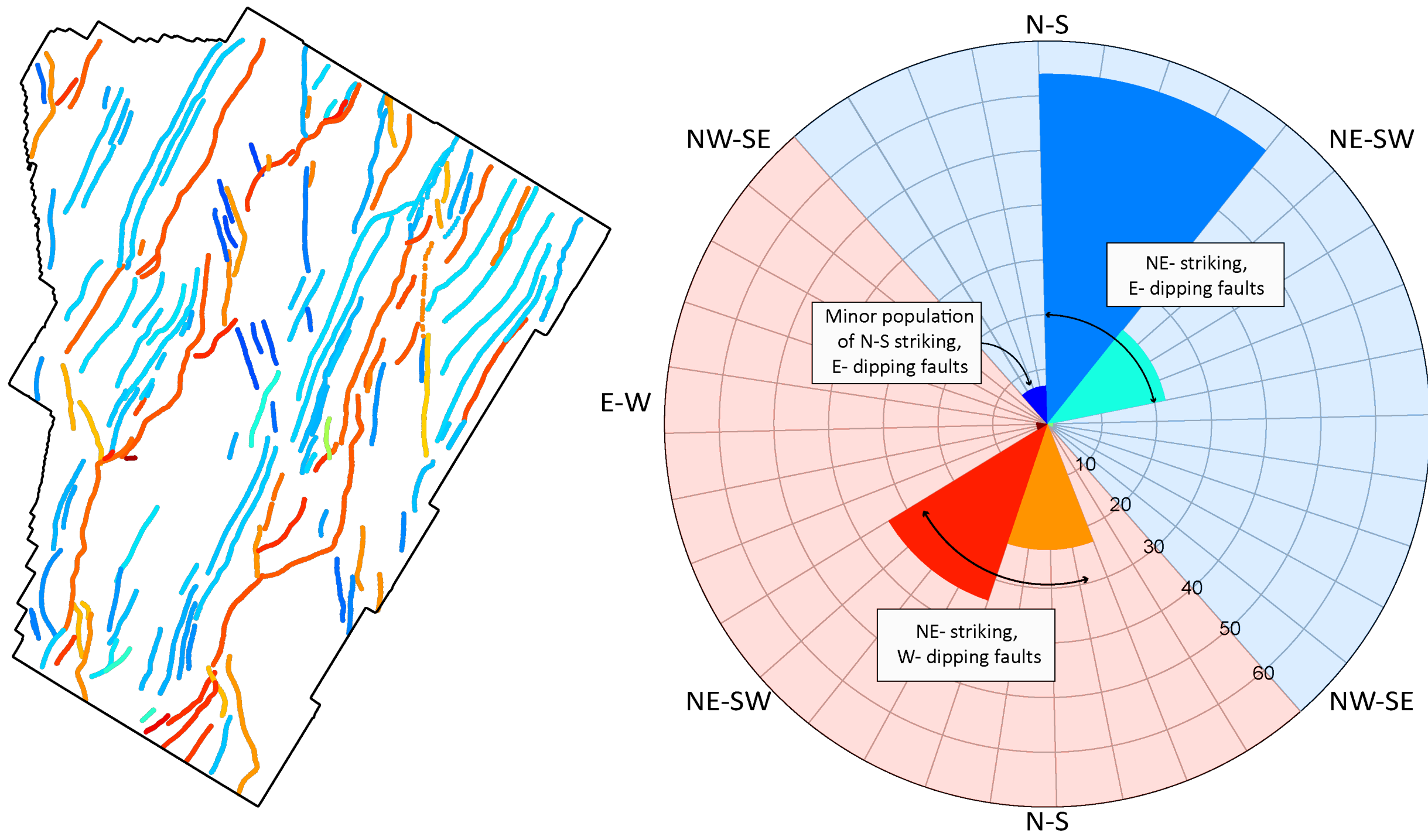

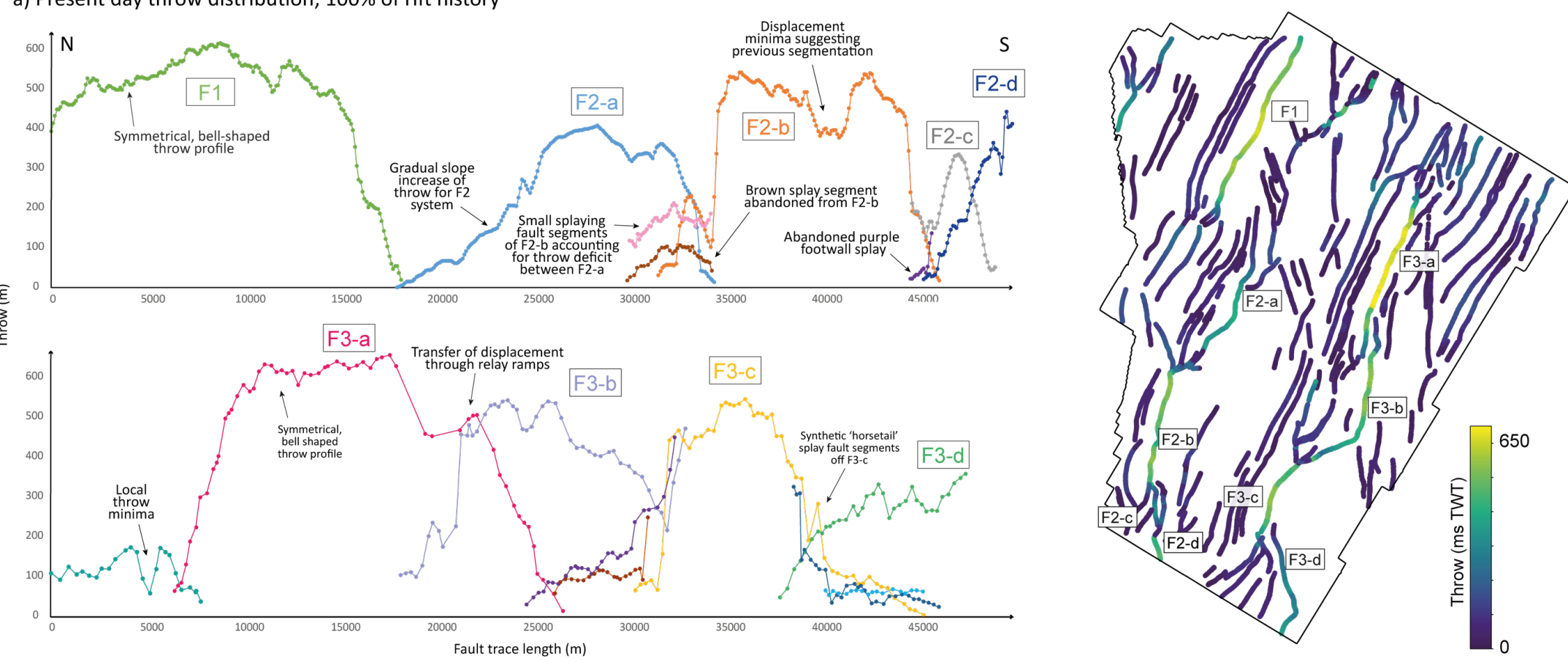

Figure 8. Throw length profiles (where fault segments are coloured by Fig 3b) with a map view of throw distribution: (a) The present day fault array, i.e. the final product of rift history; and (b) The reconstructed, backstripped fault array, where faults are backstripped to 28.5 Myrs (H4;
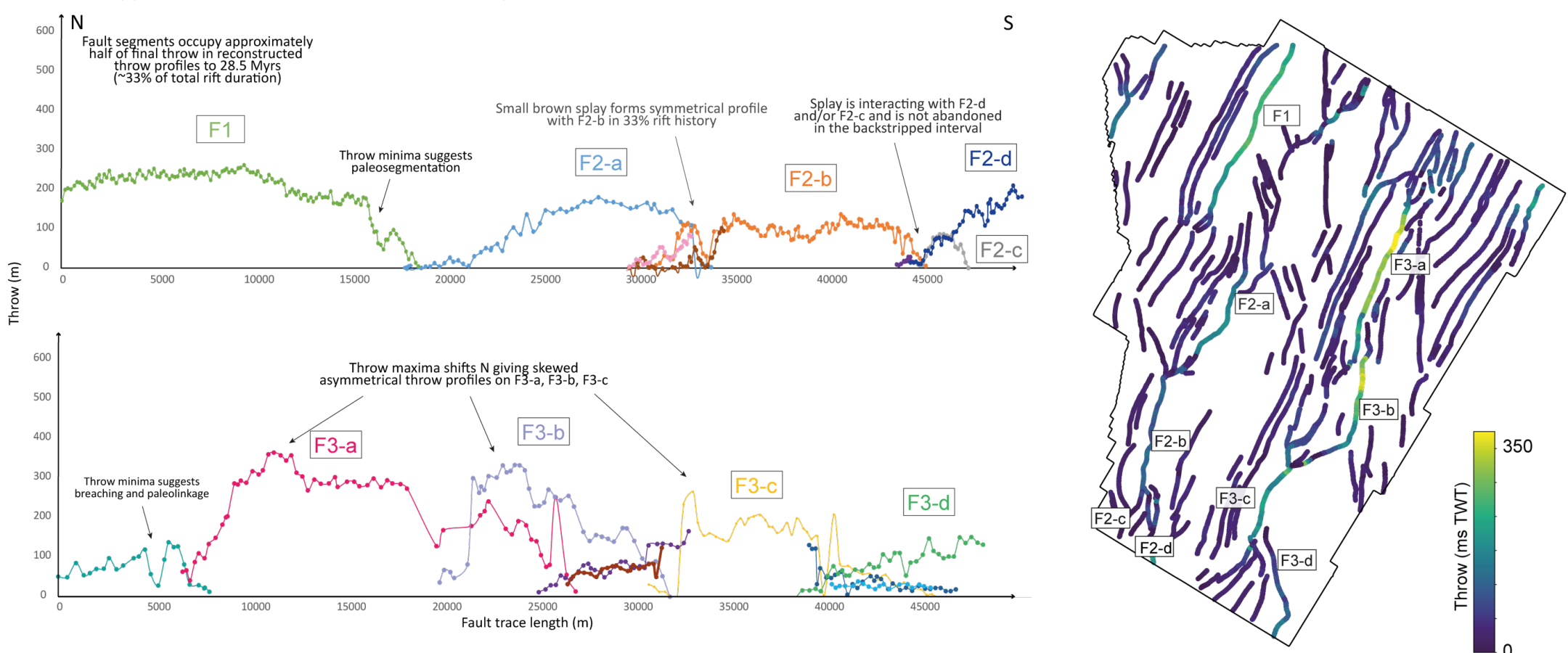
Top Murat). 
Figure 9. Isochron maps showing thickness changes between syn-depositional horizons. The syn-rift unit is divided into six, labelled as SU1-SU6.

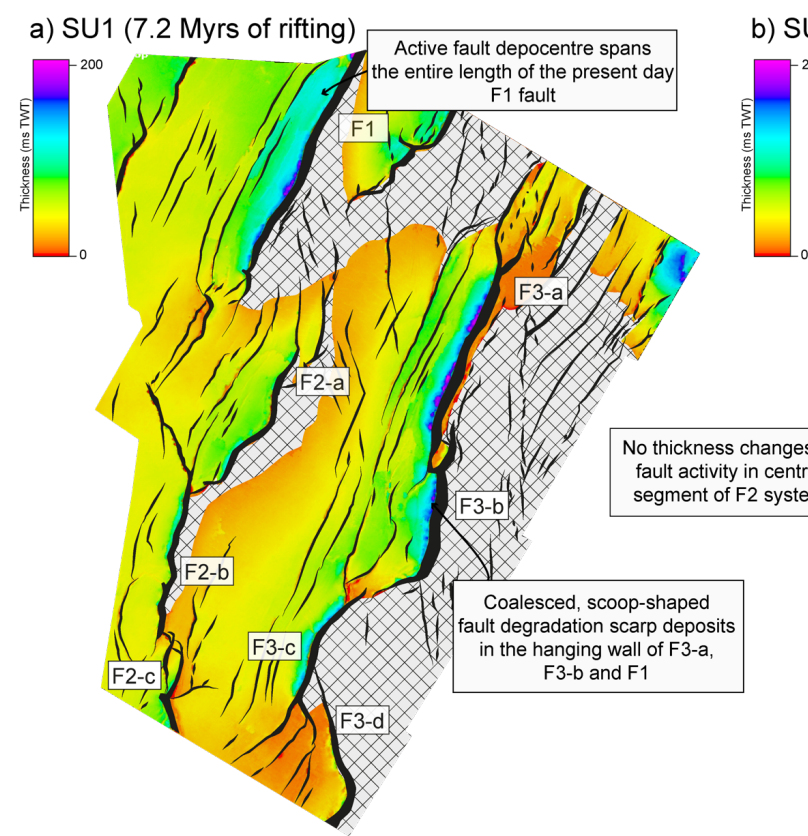

d) SU4 (2 Myrs of rifting)

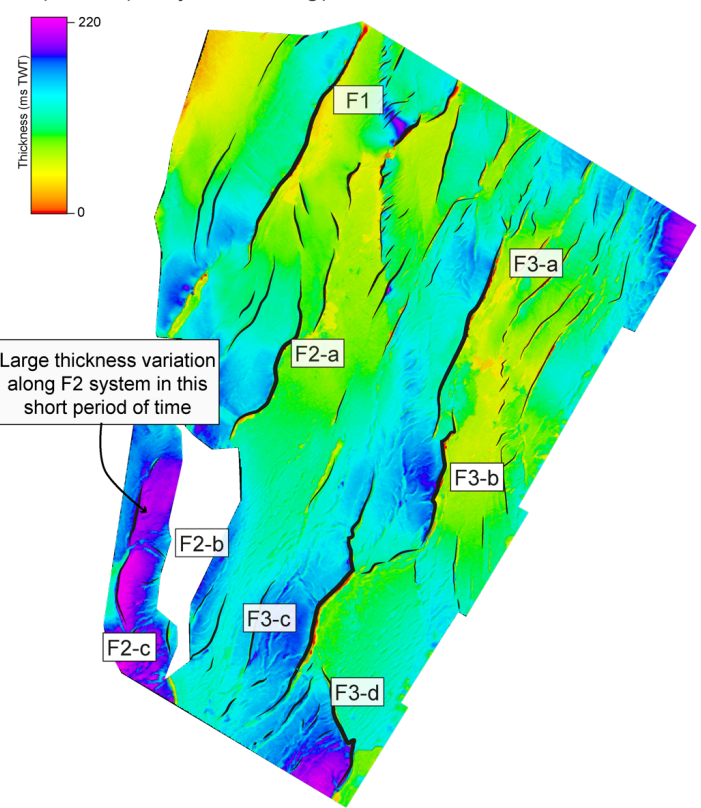

b) SU2 (21.3 Myrs of rifting)

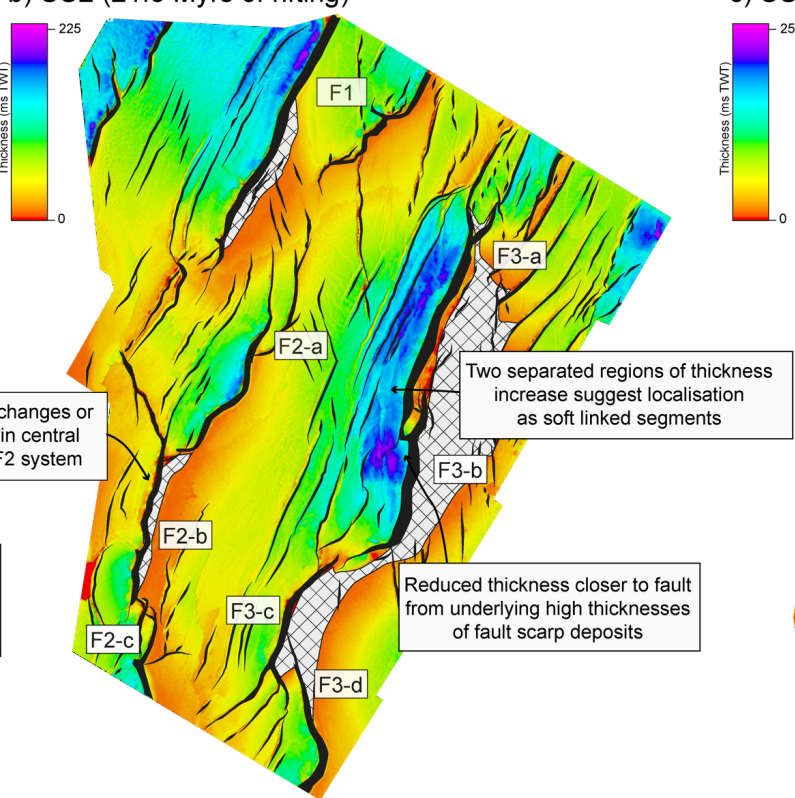

e) SU5 (3 Myrs of rifting)

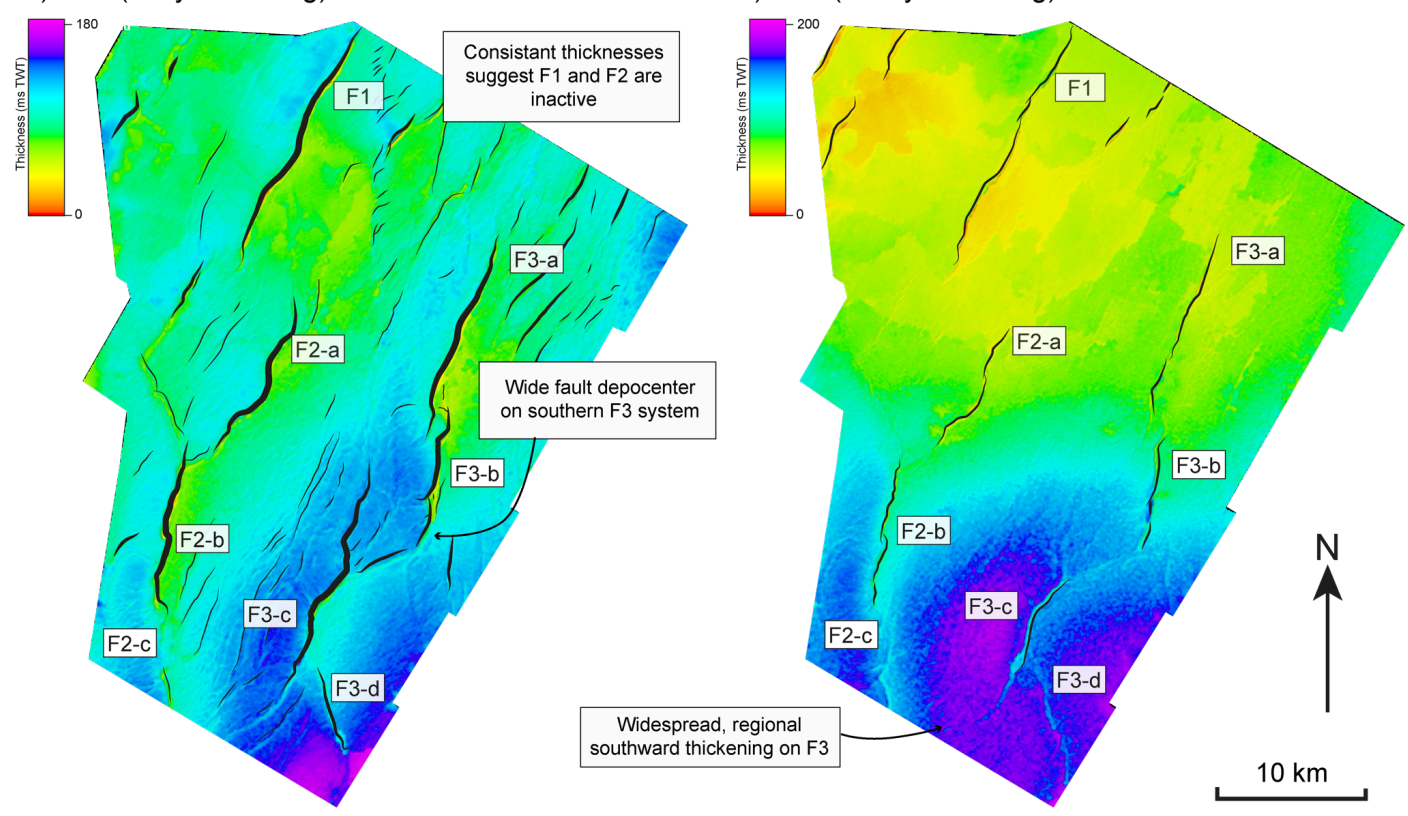

c) SU3 (37 Mrs of rifting)

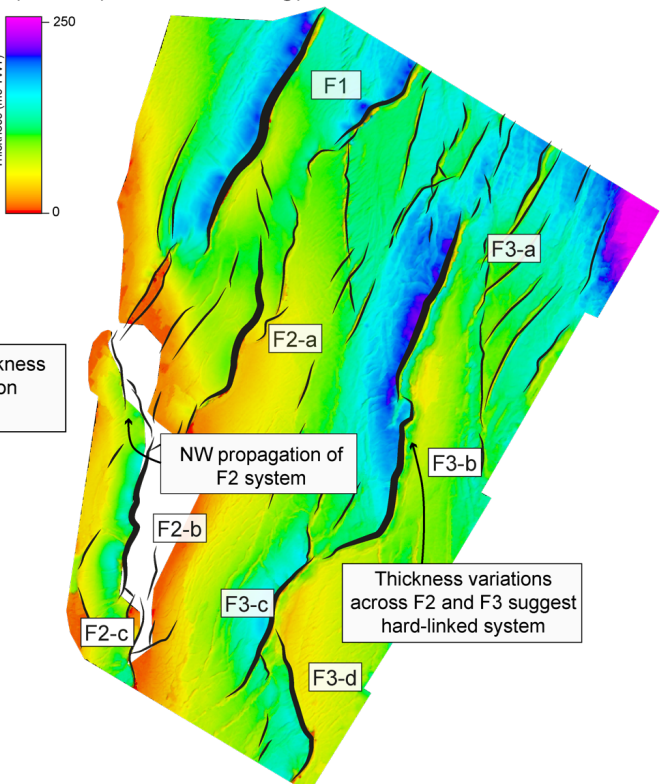

f) SU6 (15 Myrs of rifting) 


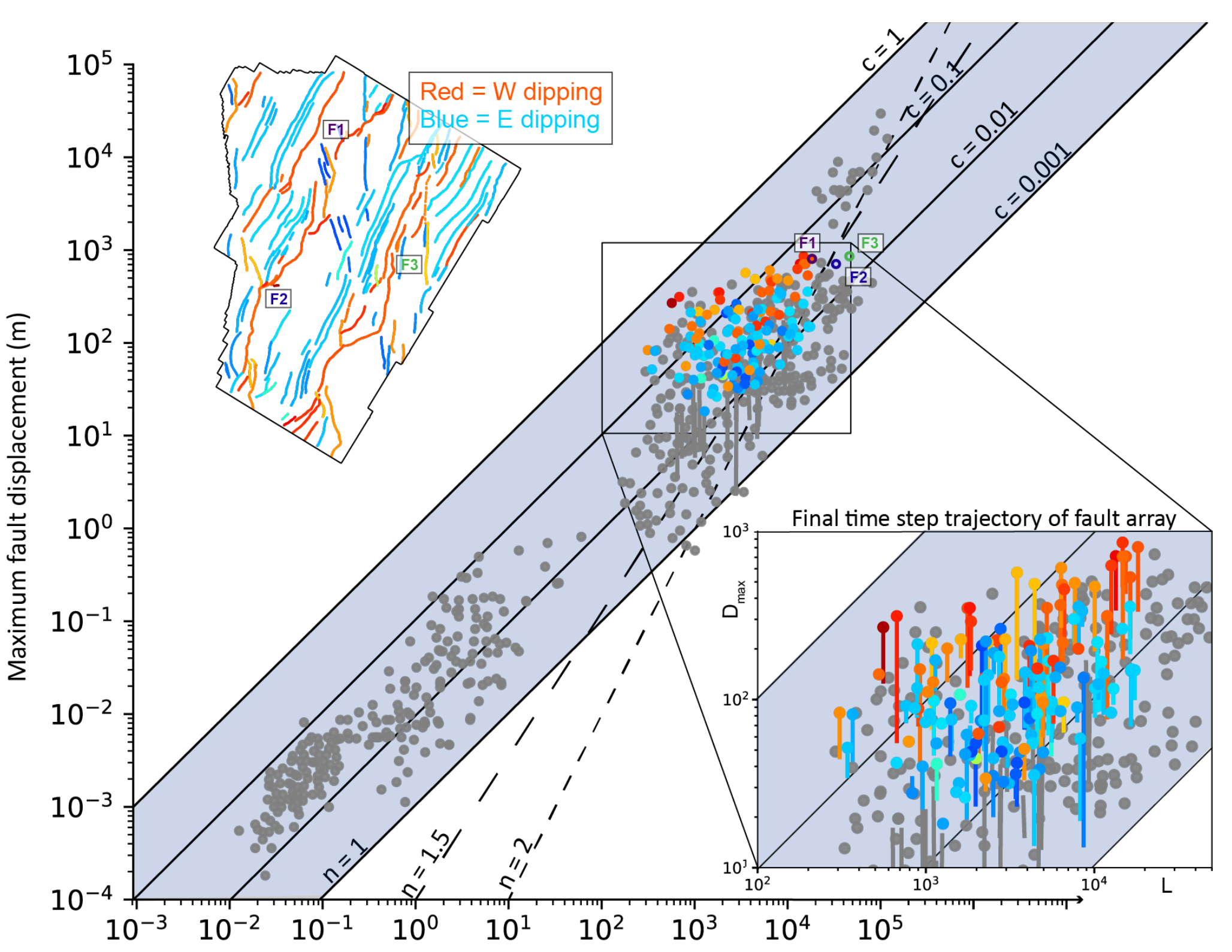

Figure 10. Our results plotted against global displacement-length data (in grey). Data is coloured by their dip (see Figure 7) whereby blue-coloured faults are east dipping, and red-coloured faults are west dipping. The inset shows the last $67 \%$ of rift history, as we connect our present-day values of fault geometry with their respective backstripped values.

Fault trace length $(\mathrm{m})$ 

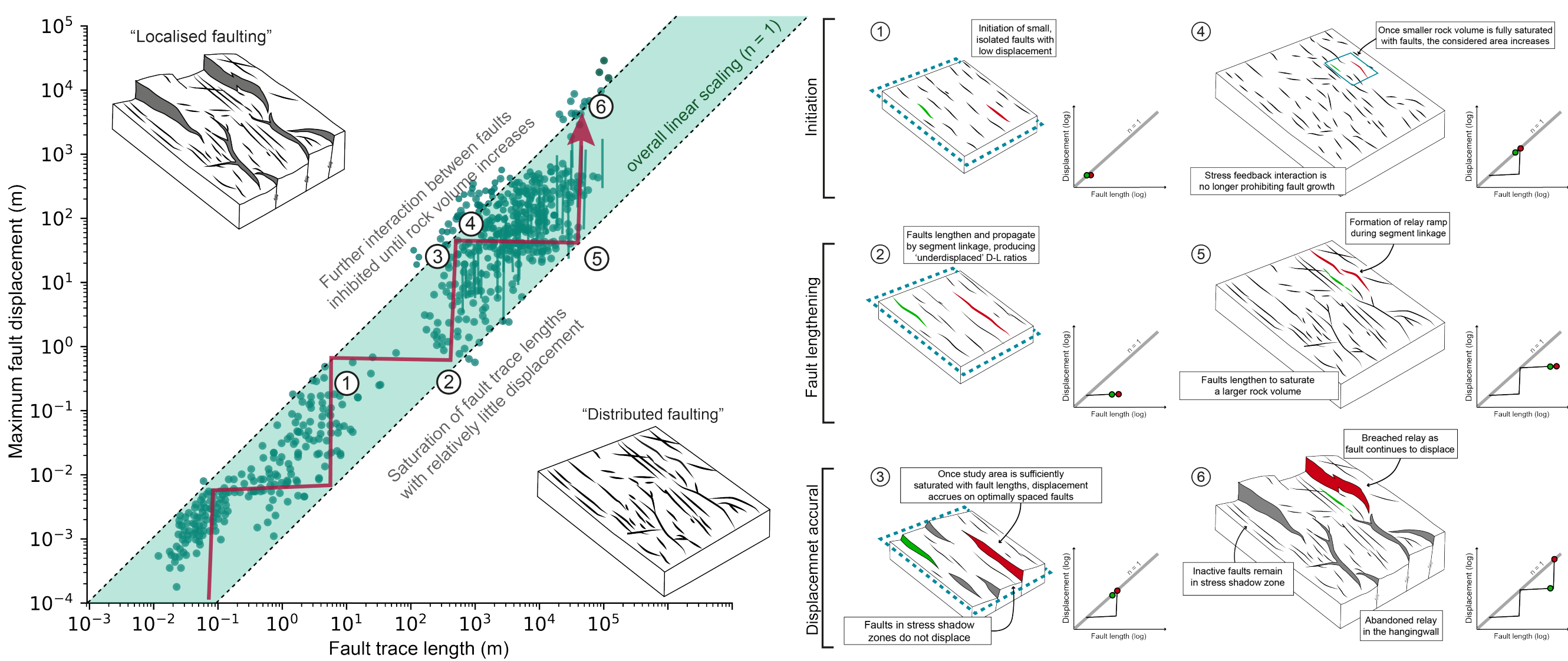

Figure 11. Our new proposed fault growth model, where the fault trajectory shows growth via alternating phases of fault lengthening (producing a near horizontal trajectory) and fault displacement (producing a near vertical trajectory). Stage 1, 2 and 3 are examples of initiation, linkage and localisation over a smaller region. Faults initiate as small numerous fault segments (1), then lengthen via segment linkage until the rock volume is sufficiently saturated, producing relatively underdisplaced D-L values (2), displacement accrues on optimally located and spaced faults (3). Once the smaller region is saturated by fault lengths and displacement, the considered region increases, allowing the fault array to undergo initiation (4), lengthening (5) and localisation (6) again at a larger scale. 